\title{
Restraining forces and drivers of supply chain collaboration: evidence from an emerging market
}

\author{
Adegboyega Oyedijo \\ Hull University Business School, The University of Hull, Hull, UK \\ Adebayo Serge Francois Koukpaki \\ K3-Cubed Limited, UK \\ Simonov Kusi-Sarpong \\ Southampton Business School, University of Southampton, Southampton, UK \\ Fahd Alfarsi \\ College of Business, University of Jeddah, Jeddah, Saudi Arabia, and \\ Ying Yang \\ Business School, Newcastle University, Newcastle upon Tyne, UK
}

\begin{abstract}
Purpose - This paper aims to investigate how restraining forces and driving forces impact supply chain collaboration in the context of Nigeria.

Design/methodology/approach - A qualitative approach was adopted. Using semi-structured interviews, data was obtained from manufacturers and third-party logistics providers in Nigeria's food and beverage sector. The data was analysed using the thematic analysis method.

Findings - Interesting findings were revealed regarding how some underlying forces impact supply chain collaboration. These findings were categorised into internal, supply chain, and external environment level factors. However, certain forces were also identified at these distinct levels which can sustain the collaboration between supply chain partners in emerging markets like Nigeria.

Originality/value - Many studies on SCM have wholly focused their attention on developed countries, often neglecting emerging markets like Nigeria in the discourse. Although supply chain collaboration has been well researched, our study attempts to shift the attention to the most populous country in Africa. With the help of the force field theory, this research reveals new insights on the restraining forces and drivers of supply chain collaboration, offering the foundation for a new line of research on this subject in emerging markets.

Practical implications - This research aids managerial understanding of the restraining forces and drivers of supply chain collaboration in an emerging market. Our research also provides new insights on how to manage supply chain collaboration in emerging markets.

Research limitations/implications - The issues highlighted in this paper create opportunities for future studies to dig deeper into the concept of supply chain collaboration in emerging markets. Future studies may find other unique contextual factors which may influence supply chain collaboration asides those identified in this paper.
\end{abstract}

Keywords: Emerging Economies, Supply chain management, Supplier-manufacturer relationships, Collaboration

Paper type Research paper 


\section{Introduction}

Since the concept of supply chain (SC) collaboration was coined by Ellram and Cooper (1990) as a driver of supply chain management (SCM), several scholars have examined the concept from different perspectives to understand its characteristics, drivers, barriers and outcomes (e.g. Matopoulos et al., 2007; Wiengarten et al., 2010; Pradabwong et al., 2017; Um and Kim, 2019). Most studies agree that SC collaboration enables high performance from both the focal firm's viewpoint and the entire SC due to resource capitalisation, and the emphasis on leveraging capabilities between firms (Fawcett et al., 2012). However, is true that collaboration across organisational boundaries is often difficult to establish and maintain due to different cultural and structural barriers (Barratt, 2004; Fawcett et al., 2015; Busse et al., 2016). Issues such as low trust levels, the negative use of bargaining power, and portrayals of opportunism have been highlighted as hindrances to developing SC collaboration (Mccarter and Northcraft, 2007; Nyaga et al., 2010; Nyaga et al., 2013). Likewise, firms today are also operating in dysfunctional silos, obstructing the development of productive collaboration (Huang et al., 2020). These varied difficulties highlight the structural and non-structural factors that may influence SC collaboration, which may also result from uncertainty (Katsikeas et al., 2009), goal incongruence (Prosman et al., 2016), and absence of governance mechanisms (Huang et al., 2014).

Though SC collaboration has received significant attention in the SCM field, there are still some shortcomings in the literature which warrant further investigation (Soosay and Hyland, 2015; Ralston et al., 2017). Most studies have either been directed towards the definition of SC collaboration from a one-sided organisational perspective (Barratt, 2004; Min et al., 2005; Cao et al., 2010), the collective outcomes or benefits of SC collaboration (Kohli and Jensen, 2015; Um and Kim, 2019), or its impact on performance (Vereecke and Muylle, 2006; Panahifar et al., 2018). To date, research on SC collaboration in emerging markets is at a nascent stage (Orji et al., 2019; Ugoani, 2019). Emerging markets are important because of their growth potential and the prospective impact that they can have on global trade and economy, compared to their developed counterparts. However, emerging markets are also volatile due to numerous issues such as political instability, infrastructural challenges, regulatory systems, lack of transparency, etc. Thus, the knowledge gained from developed economies may not work for emerging economies. Consequently, this study responds to wider calls in the literature (Fawcett et al., 2008; Soosay and Hyland, 2015) to expand knowledge about SC collaboration for a better understanding of the country-specific aspects of the concept (Cao and Zhang, 2011; 
Ramanathan and Gunasekaran, 2014; Fawcett et al., 2015; Chen et al., 2017). We, therefore, pose the research question: in what ways do restraining forces and driving forces impact SC collaboration in emerging markets?

This exploratory study focuses on the food and beverage $(F \& B)$ sector of an emerging market (Nigeria), examining the driving forces and restraining forces of SC collaboration. The motivation of this study is threefold. First, the Nigerian context provides a rich, fruitful, and unique empirical setting for examining SC collaboration challenges since it is an emerging and increasingly globalised market (Muogboh and Ojadi, 2018), representing an area that is "neglected" and not well "understood" where SCM discourse is concerned (Adebanjo et al., 2013; Ojadi et al., 2017). It is surprising that only a few studies have been conducted in this region considering that Nigeria is the 7th most populous nation on the planet (United Nations, 2019), and the most populous, and largest economy in Africa (IMF, 2019). Second, Nigeria's position in the growth of Africa's economy is significant because of its role as a supplier of some major commodities (Muogboh and Ojadi, 2018). However, efficiently and effectively running SCs in Nigeria can be a complicated task, with numerous manufacturers, retailers, suppliers and third-party providers responding to the demand of a growing population of over 200 million people in a developing economy (Orji et al., 2019). Lastly, the F\&B industry has not been well-researched in terms of SC collaboration and SCM even though this sector plays an essential role in the global and regional economy by meeting the needs of people (World Bank, 2018).

To improve the current understanding of SC collaboration, we have adopted the force field theory (FFT) (Lewin, 1951), which argues that collaborations will have both driving and restraining forces that influence them. Driving forces are positive as they push in the desired direction of SC collaboration, while restraining forces are negative as they lead SC collaboration in an undesirable direction. Equilibrium is reached when the sum of driving forces equals the sum of the restraining forces.

In response to calls in the pertinent literature for research on SC collaboration in emerging markets (Flynn et al., 2014; Arora and Hartley, 2020), the findings of this research contribute to SC collaboration theory by proposing a model which underpins the driving forces and restraining forces of SC collaboration. In particular, this study pinpoints the amplification of these driving and restraining forces, based on the contextual realities of emerging markets. Hence, this research provides further insight into the continuing challenges of SC collaboration 
from three distinct levels and how they can be managed effectively. From a practical viewpoint, the findings of this study provide new ideas for managers to further understand how SC collaboration can flourish amidst the unique features of emerging markets. The results of this research can also be used to map out new strategies for improving the performance of SC collaboration to reap the full benefits in such contexts.

The rest of the paper is structured as follows. The next section presents the theoretical background first, and its application on SC collaboration. Thereafter, the research methods are explained with the qualitative approach and data analysis. Next follows a discussion of the research findings and the implications are presented. Finally, we conclude the article with some suggestions for future research based on the limitations of the study.

\section{Theoretical background}

\subsection{Force field theory}

The FFT is a change management diagnostic technique developed by Lewin (1951). It helps to identify variables involved in the planning and implementation of successful SC collaboration. It suggests that driving forces and restraining forces need to be fully considered when pursuing a means for collaboration. FFT has not often appeared in SC collaboration studies, but it illustrates the forces that resist change and those that drive change in a situation (Swanson and Creed, 2014). Such forces that resist change may include but are not limited to lack of senior management support, inadequate technology, organisational culture and structure, people, policy and processes, opportunism, power imbalance and information quality (Fawcett et al., 2010). However, driving forces include goal alignment, trust, technology advancement, supplier development, etc (Soosay and Hyland, 2015). This organisational theory underpins the concept of SC collaboration as it proposes the need for practitioners to pay close attention to the restraining and driving forces that trigger collaboration capability. Thus, FFT has been adopted to explain the internal and external level factors that affect SC collaboration (restraining forces) and the possible solutions or bridges to these factors (driving forces).

FFT is also useful for making decisions relating to the effectiveness of various SC collaboration structures and systems, government policies that present patterns of behaviour as a way of managing resistance to change in SC collaboration (Swanson and Creed, 2014). In addition, it also helps to identify the need for change in SC collaboration. Viewed from this perspective, FFT could be used at three different levels in SC collaboration. First, at an 
individual level, for those who work in each partner firm such as boundary spanners (Dekker et al., 2019), FFT helps in changing their skills, values and eventual behaviour - making sure that such individual behavioural change is always regarded as instrumental to SC collaboration. Second, FFT enables changes in various SC collaboration networks structures and systems e.g. reward systems, reporting relationships, and the design of SC collaboration. Finally, it directly impacts on SC collaboration climate or interpersonal style such as the level of openness between SC partners, how conflict is managed, how decisions are made (Mabey et al., 1993).

\subsection{Force field theory and supply chain collaboration}

Collaborative activities represent each party's willingness to give and take in their relationship and this allows the relationship to adapt over time and creates an avenue for on-going administration of the exchange (Cai et al., 2013). Srinivasan and Brush (2006) stated that these activities promote cooperative behaviour and increase the potential value of the exchange relationship. The FFT perspective helps us to examine three types of collaborative activities. These are: information sharing, joint relationship effort, and dedicated investment as they represent value-adding relational norms (Bhakoo et al., 2012; Buijs and Wortmann, 2014). Each of these activities are explained below.

Information sharing has become an important aspect among organisations as value-creating factors are shifting from physical and financial assets toward intangible assets (Koçoğlu et al., 2011). Information sharing refers to the extent that critical information is conveyed to a party's relationship partners (Kembro and Näslund, 2014). This may include involving other parties in the early stages of product design, opening the books and sharing cost information, discussing future product development plans, or jointly providing supply and demand forecast (Cannon and Perreault Jr, 1999). Communication between SC partners has been recognised as a key ingredient for any SCM system (Moberg et al., 2002), and will bring forth competitive advantage in the long run ( $\mathrm{Li}$ and $\mathrm{Lin}, 2006)$. Information sharing is considered as one of the five building blocks that characterise a solid SC relationship (Lalonde, 1998; Cai et al., 2013), and a critical factor if partners want to realise the benefits of relationships ( $\mathrm{Li}$ and Lin, 2006). Thus, from the FFT perspective, we argue that the strength of information sharing between SC partners may produce a driving force to enhance SC collaboration, while withholding information may create confrontation or tensions. To succeed with information sharing, all three levels explored above must be included. At the individual level, people must align their attitudes, values and behaviours to support SC collaboration. Second, the collaboration itself 
should implement structural and systemic approaches to be effective. Third, an open and interpersonal climate is needed to enable effective collaboration.

The success of SC relationships is largely dependent on the collaboration of SC partners to plan and coordinate activities, and resolve problems (Nyaga et al., 2010), termed a 'creative climate'. Joint relationship effort consisting of joint decision-making and joint-problemsolving are perceived as a natural extension and are largely dependent on information sharing between SC partners (Min et al., 2005; Pimentel Claro et al., 2006). Joint planning is essential in SC relationships to co-align operations and capacities which have a positive influence on relationship quality (Min et al., 2005; Orji et al., 2019). The importance of joint problem solving has also been recognised to result in mutually developed processes of improvement (Min et al., 2005). It was also found that joint effort between SC partners such as planning, goal setting, performance measurement, and problem solving, is significant for successful SC relationships (Min et al., 2005; Pimentel Claro et al., 2006; Soosay et al., 2008). As argued earlier, restraining forces are usually present in SC collaboration as more powerful buyers exhibit bargaining and purchasing power during exchanges. Therefore, it is paramount to promote collaborative activities to achieve agreeable outcomes.

Sustainable relationships need to be supported with sufficient resource investments (Min et $a l .$, 2005). Dedicated investments are investments which are dedicated to a relationship between SC partners (Heide and John, 1990; Wiengarten et al., 2010; Bhakoo et al., 2012). Dedicated investments are also critical for SC relationships as they offer tangible evidence that a partner can be believed, cares for the relationship, and is willing to go the extra mile with such investments (Ganesan, 1994). These investments have been recognised as communicating a strong commitment to the relationship because of the economic consequences that the other party will incur if the relationship ends (Min et al., 2005; Nyaga et al., 2010). From the FFT perspective, sustainable relationships are guided by the strength of driving forces that positively impact SC collaboration through openness, trustworthiness, and the ability to deal with restraining forces linked to SC collaboration.

\subsection{Collaborative activities, relationship quality, and supply chain performance}

Past studies have recognised the benefits of collaborative activities between SC partners to include risk sharing, cost reduction, enhanced rapid learning capacity, knowledge transfer, and sustainable competitive advantages (Li et al., 2006; Nyaga et al., 2010; Cai et al., 2013). Dedicated investments offer tangible evidence of a partner's commitment to a relationship, 
which will in turn increase the level of trust and satisfaction in the relationship (Anderson and Weitz, 1992; Jap and Ganesan, 2000). Kwon and Suh (2005) state that inter-firm communication is essential in the trust-building process since the sharing of critical information and communication allows businesses to develop a mutual understanding of each other's routines and develop mechanisms for resolving conflicts, which indicates that the partner is trustworthy (Cai et al., 2013). High-level of information sharing minimises uncertainty, which results in improved levels of trust and commitment in an SC relationship. Several studies suggest that joint relationship effort enables partners to co-align their processes and make joint decisions, which enhances the relationship by building trust (Nyaga et al., 2010; Chu and Wang, 2012; Orji et al., 2019), commitment to the relationship (Jap and Ganesan, 2000), and relationship satisfaction (Walter et al., 2003). Collaborative activities also have significant advantages for performance (Cao and Zhang, 2011).

However, there are still a number of avenues open for research which explores the concept of SC collaboration further, particularly due to the complex nature of collaboration being structural, and process and relationally based (Soosay and Hyland, 2015). The majority of studies on SC collaboration in the literature have either been directed toward its effects or the performance impact. For example, a study conducted by Simatupang and Sridharan (2005) used an instrument to measure the practice of SC collaboration through a survey of companies in New Zealand and they found that collaboration index was positively linked with operational performance. Similarly, a study by Liu et al. (2020) found that SC collaboration improves firm operating performance in China. Likewise, Fawcett et al. (2008) examined the factors that lead to effective SC collaboration with managers based in the US and found that information sharing, technology, culture, trust, etc are major barriers. Another study conducted by Wiengarten et al. (2010) examined the relationship between collaborative practices and performance within the German automotive sector and found that the impact of collaborative SC practices on performance varies significantly depending on the level of information quality. Although the impact of SC collaboration is a vital consideration in theory and practice, it is equally vital to understand how SC collaboration is influenced by different factors (Fawcett $e t$ al., 2008; Soosay and Hyland, 2015; Huang et al., 2020).

Moreover, the majority of studies on SC collaboration have been conducted in developed markets such as USA, UK and Taiwan; there are significantly fewer studies related to emerging markets, especially those in Africa, which limits our current understanding (Soosay and Hyland, 2015). In the context of emerging markets, a report by Cadilhon and Fearne (2005) 
considered SC collaboration in Vietnam and found that effective SC collaboration can be built on key dimensions of SC collaborative practices. Likewise, a study by Vieira et al. (2009) which examined collaboration intensity in the Brazilian supermarket retail chain, found that interpersonal integration offers greater benefits to collaboration than other integration factors. Bezuidenhout et al. (2012) analysed SC collaboration in three South African sugarcane milling areas and found that a lack of attributes such as stability, reliability, trust, personnel relationships and communication can lead to fragmentation, opportunism and other negative behaviours. In India, Kumar et al. (2017) found that collaboration is among the critical success factors that influence SC performance. Furthermore, in Malaysia, a study by Shukor et al. (2020) which examined the impact of environmental uncertainty and organisational ambidexterity on SC collaboration, found that a strong relationship exists between organisational ambidexterity and SC collaboration, and SC collaboration was revealed to have a positive impact on SC agility and organisational flexibility.

In summary, past studies have recognised the significance of SC collaboration for financial and non-financial performance. In developed countries, scholars have explored the factors that influence SC collaboration, and how it can improve overall SC performance while serving as a source of competitive advantage for organisations today. Likewise, past studies on SC collaboration in emerging markets have also recognised its benefits in this context. However, scant studies have examined the driving forces and restraining forces that impact SC collaboration in the context of emerging markets, which are the focus of this study.

\section{Methodology}

\subsection{Qualitative study}

Despite the extensive literature on SC collaboration, there has been limited engagement with collaborative supply networks, especially relationships between manufacturers and third-party logistics providers. Based on our research question, this study adopts a qualitative approach to develop theory about the restraining and driving forces impacting SC collaboration between manufacturers and third-party logistics providers in an emerging market (Merriam and Tisdell, 2015; Creswell and Poth, 2016). Although extensive literature has considered the concept of SC collaboration from different angles, our current understanding of this subject in emerging markets still warrants further investigation. Thus, we approached the study as one of 'theory elaboration' (Lee et al., 1999), in which our goal was to extend the theory around a conceptual 
area from the FFT perspective, rather than build new theory. Lee et al. (1999) posits that 'theory elaboration occurs when pre-existing conceptual ideas or a preliminary model drives the study's design. Our research focuses on the Nigerian food and beverage (F\&B) industry as the context of this study. Thus, the qualitative approach was adopted to allow us get a detailed description of certain occurrences and experiences (Merriam and Grenier, 2019). As we elaborate on existing theory, this study provides rare insights and understanding of SC collaboration from an emerging market's perspective.

\subsection{Research setting}

The F\&B sector represents $22.5 \%$ of Nigeria's manufacturing industry, $66 \%$ of total consumer expenditure, and an aggregate industry output valued at about $\$ 20.55$ billion, equivalent to $4.6 \%$ of gross domestic product (GDP). However, SC costs are very high, which has a negative impact on performance (Adebayo, 2012). There have been persistent structural and policy challenges, and wide infrastructural gaps have been highlighted as overarching issues (Oyedijo, 2011; Gado, 2015; IMF, 2019; CIA, 2020). For SCs, different issues have been mentioned such as weak visibility, poor information sharing, insufficient joint relationship effort, and minimal dedicated investment between SC partners. Likewise, heavy vehicular traffic, accidents and breakdowns on several intra and inter-city highways result in a lot of delays which affect lead times and product deliveries, and in turn, increasing the costs of operations and minimise efficiency and product delivery levels (Ugonna et al., 2015).

In terms of the uniqueness of this context, most manufacturers sell their final products only to businesses (third-party providers), who sell them to other actors along the SC such as, retailers, transporters/distributors, and end consumers. These distributors are referred to as "middlemen" or "marketers", who stand in the gap between manufacturers and end consumers in the form of third-party providers (see Figure. 1).

Insert Figure 1 about here: Supply chain in Nigeria's food and beverage sector

The top manufacturers in the industry include Guinness Nigeria Plc, Consolidated Breweries, Nigerian Bottling Company Ltd, Cadbury Plc, Nigerian Breweries, Fan Milk Plc, 7UP Bottling Company Plc, and Coca-Cola Nigeria Plc. The middlemen often undertake the relationship management function, which involves feeding information back to manufacturers regarding customer needs and concerns about their products. They also often act as a two-way 
voice mechanism for both the manufacturers and other SC members on the chain's right-hand side. However, although these third-parties have a key influence in the flow of goods and services along the chain, structural and non-structural challenges are still encountered. The collaboration between third parties and other actors in the SC is often fragmented. Thus, the F\&B sector in Nigeria provides a unique research context to study this important topic.

\subsection{Informant selection}

We focused on the interaction between suppliers (F\&B manufacturers) and their buyers (thirdparty logistics providers) (Nyaga et al., 2010; Brito and Miguel, 2017). Thus, our informants consisted of eleven suppliers and eleven buyers, resulting in 22 qualitative interviews (see Table 1). The informants were selected using the following criteria:

- organisations should be in Nigeria

- access to suitable interviewees must be available to aid triangulation

- organisations should be part of a SC

- firms should have experiences of managing third-parties in the SC and vice versa.

We collected data from participants who were well informed about the procurement and supply management processes and the implications of supplier collaborations. Interviewees were determined using a purposive sampling approach as it gave the researchers the chance to use judgement to select subjects that would best assist in answering the research question, meet the research objectives, and contribute new insights to the research (Saunders et al., 2009). Their positions covered various aspects of procurement, merchandising, sales, distribution, supply, logistics, and projects directed towards collaboration (see Table 1).

\subsection{Data collection process}

The main data collection was carried out using the semi-structured interviewing technique. This approach provides a relatively open format, yet focuses on specific issues, which allows the researcher to guide the interviewee through the areas to be discussed (Saunders et al., 2009; Easterby-Smith et al., 2012). At the start of the data collection process, we obtained a list of F\&B manufacturers in Nigeria from the Nigerian Association of Chambers of Commerce, Industry, Mines and Agriculture (NACCIMA) and the Lagos Chamber of Commerce and Industry (LCCI). We also established contact with manufacturers through visits to their plants and offices in different parts of Nigeria. Most interviews were conducted in a face-to-face format. The interviews were audio-recorded, adding to an accurate, unbiased record, and 
allowing the opportunity for direct quotations (Voss et al., 2002; Saunders et al., 2009). We established contact with these firms using an initial invitation letter that stated our research's aim and objectives. We also had a few follow-up telephones calls to arrange interview dates. All interview respondents asked to be kept anonymous. The interviews were held with a total of twenty-two purchasing and supply executives and their positions are displayed in Table 1. The interviews conducted lasted between forty-five minutes to an hour. We utilised an interview guide, recorded, and transcribed the interviews through an ethical procedure. The interview protocol was piloted with two interviewees prior to the main data collection. The whole process of data collection and analysis took a year and a half to complete.

Insert Table 1 about here: Interview details and respondents' features

\subsection{Data analysis}

The thematic analysis method was used to analyse the data, organise the data, and report the subsequent findings (Easterby-Smith et al., 2012). It followed the three steps suggested by Miles and Huberman (1994) which are data reduction, data display, and conclusion. We began by identifying patterns and transferring codes to extracts which were indeed related to the research question. For clarity and completeness, the researchers read the transcripts several times to familiarise themselves with the data, and find repeated patterns of meanings and issues related to the subject matter. Subsequently, the coding approach suggested by Corbin and Strauss (1990) was followed, and three categories were developed: first-order (open coding), second-order (axial coding), and third-order themes (selective coding). From the examples provided by the interviewees, we began with the reduction of data to quotes, sentences, or paragraphs with the highest level of significance to answering the research question. This enabled us to choose first-order codes. Subsequently, using axial coding, interconnections between first-order quotes were identified and grouped into descriptive second-order categories by searching for key categories related to the barriers and drivers of SC collaboration within the illustrative quotes. Some of the second-order codes were deduced from the pertinent literature on SC collaboration while some were new due to the unique nature of the context (Table 2 for representative data for these codes). In selective coding, descriptive second-order categories were regrouped into distinct third-order categories in line with the restraining forces and drivers of SC collaboration in Nigeria. The third-order themes were divided into three distinct levels based on their business contexts, relationships, and the environment in which they operate. For example, situations coded under internal ethical issues were those related to 
the barrier of SC collaboration such as bribery, corruption, insider abuse etc. The selected themes for analysis were related to the data set (Patton, 2015), due to their predominance through the data and significance to the research question. To ensure trustworthiness, some participants were contacted again for their comments on the final coding. Based on this step, some codes were dropped or rephrased to reflect their insights.

\section{Findings}

In analysing our data, we were able to unravel specific details about the research topic, especially concerning the nature of SC collaboration in a very unique environment, the major reasons why SCs struggle to achieve a high performance in this context, and some possible strategies/remedies to overcoming these challenges moving forward. In answering our research question: in what ways do restraining forces and driving forces impact SC collaboration in emerging markets, we found that restraining and driving forces impacting SC collaboration could be divided into three main dimensions: internal firm level, SC level, external environment level issues.

\subsection{Restraining forces of supply chain collaboration}

\subsubsection{Internal firm level issues}

The findings reveal that challenges associated with SC collaboration in emerging markets like Nigeria are related to issues internal to the manufacturing firms and their third-party providers. Each of the issues related to this theme are explained below, based on the insights from the interviewees.

\subsubsection{Human behaviour and people in supply chain firms}

We found that behavioural issues and lack of accountability at the individual level have a negative impact on the prospects of having a successful SC collaboration between the manufacturers and their third-party providers in Nigeria. These findings also support the point that human behaviour is critical in SC management and has the potential to disrupt the SC collaboration process. This was explained in the following illustrative quote by a Merchandise Manager who stated that:

"We also have people who just make things very complicated and often affect the management aspect of the collaborations" (Merchandise Manager G) 
It seems that the need to collaborate or the value of collaboration is not widespread in this region. This is because some practitioners mentioned that it is often difficult to carry out fundamental collaborative activities in SCs regardless of their position in the chain. Thus, there is a need to promote the value of collaboration in the SC, especially because of the challenges associated with the environment. Although collaboration may be implemented at the firm level, individuals still play a crucial role in developing and sustaining this collaboration. This point was explained by a Purchasing Director who emphasised how human behavioural factors can influence collaboration in a SC:

"Many of the personnel we deal with regularly clearly need a lot of training and knowledge on how to deal with supply chain members. Some people act as if they are not willing to collaborate or we are forcing them to partner with us" (Purchasing Director I)

At the firm level, there were complaints about certain expectations from the manufacturers which may be unrealistic or unfair as perceived by the third-party provider. Such impractical expectations from manufacturers often do not acknowledge the conditions of the environment where these businesses operate, which include weak infrastructure, poor technological systems for inventory management, tracking, and supplier relationship management applications. Likewise, there is a poor level of human interaction and resolution to challenges that occur regularly. These factors may influence the collaboration between manufacturers and their thirdparty providers and the potential for relationship development. Again, these findings stress the important role of people and human behaviour in SC collaboration. Thus, firm representatives between the F\&B manufacturers and the third-party providers need to improve their knowledge on new approaches to managing collaborative relationships in a complex environment like Nigeria. This point was emphasised by a Supply Executive in the following illustrative quote:

"The relationship often becomes difficult to handle due to some of the unrealistic demands that our suppliers give. Some people act and behave in a very irrational way especially when making critical decisions on the relationship"' (Supply Executive K)

\subsubsection{Internal ethical issues}

A major problem in emerging markets like Nigeria is business ethics, where there is a thin line between the concepts of right and wrong behaviour. An issue that is particularly rampant in this environment is corruption. The issue of corruption is widespread in public and private businesses, and it happens internally and externally. Internally, this issue distorts the potential for effective and efficient collaboration between SC partners. For example, one top firm 
representative in the third-party provider might bribe a top firm representative in the manufacturing firm to gain certain benefits and incentives which could influence the collaboration negatively on the long run. Such an unethical act can result in sluggish behaviours on the part of the third-party to perform tasks critical to the requirements of other chain members. The third-party may feel untouchable since they have paid their way through the supplier or third-party selection process. This may have significant repercussions for essential collaborative practices such as flexibility, joint relationship effort, dedicated investments to the relationship etc. The following illustrative quote by a Supply Chain Project Manager explains this point:

"Corruption, bribery, and other fraudulent practices are factors that affect our ability to perform well. Some companies bribe to get specific favours and superiority from manufacturing firms, which produces unfair competition' (Supply Chain Manager U)

Concerns about the fact that the relationship between the manufacturers and third-party providers are often initiated based on a "Guanxi" type of network where some top firm representatives use social networks of power to establish business relationships. Although this is not uncommon, especially with cultures in Asia and Africa, our findings show that collaboration is often difficult to maintain on a long-term basis due to the foundation of the relationship being based on social ties instead of a rigid selection process. This corporate corruption at the firm level leads to favouritism, partiality, and opportunistic behaviours which affects SCs in Nigeria. Thus, it may be difficult to collaborate effectively amid these issues where ethical values are often missing. This point is illustrated by a Key Accounts Manager as follows:

"Many firms in the supply chain are also owned by executives and top managers in manufacturing firms. So, there is a lot of insider abuse and negative use of power for personal favouritism and partiality' (Supply Manager V)

These ethical issues and the corrupt nature of the business environment also create an avenue for some individuals to act and seek personal gain in both the manufacturing and third-party firms. Some firm representatives use these opportunities to increase their own monetary and non-monetary gains. This is, however, not surprising considering how some SC relationships are formed with nepotism etc. These practices often hinder SC collaboration since some parties use bargaining or purchasing power opportunistically for a one-sided gain. A Logistics Manager explained this point as follows: 
"Due to the nature of the business environment and the weak corporate governance in the supply chain, we have many businesses existing but are owned by some senior people in the manufacturing firms and what they do is to use their position to seek their personal benefits first before anything else. This of course creates a market that benefits some and not all'" (Logistics Manager D)

\subsection{Supply chain level issues}

Similarly, our findings also reveal challenges at the SC level, affecting the collaboration of SCs in Nigeria. We found two important factors which are discussed below, based on the insights from the interviewees.

\subsubsection{Weak information technology infrastructure}

Aside the firm level challenges, respondents also mentioned issues that exist at the SC level, particularly relating to poor technology systems. Most interviewees both at the manufacturer and third-party side agree that a major issue affecting their SC collaboration is the current weak technology system being used. Most of these systems are old and are not able to help both parties collaborate to meet the increasing demand from end consumers. One Logistics Operation Manager said the following, which illustrates the point:

\section{“Ifeel our technological landscape needs rapid advancement' (Logistics Manager I)}

Most respondents stated that there is a need to invest in different information technology (IT) infrastructure to aid collaboration between $\mathrm{F} \& \mathrm{~B}$ manufacturers and their third-party providers by improving track and trace, joint contingency plans, and sharing information beyond the first tier. Some interviewees expressed that they currently lack IT systems to support their decision making on important aspects of their SCM, which is explained below:

"We lack advanced ICT systems that can support our decision making on aspects of the supply chain management process, such as forecasting, planning and control, distribution and inventory management'” (Inventory Manager N)

These IT systems also impact the ability to share important information between the manufacturing firms and the third-party providers. Such real time information is needed to collaborate in an environment like Nigeria where there are regular power cuts which often influence manufacturing abilities. Robust IT systems can help minimise risks related to order forecasting and reduce costs for both parties. A Supply Director explains this point further: 
"There are no optimisation systems available to share critical information on-time with our supply chain members on critical aspects such as product modification and changes to orders. So, we spend a lot on purchasing internet Wi-Fi and telephone minutes to enable communication via email and telephone", (Supply Director P)

Thus, there is a need to invest in technology systems to improve the level of collaboration between SC partners.

\subsubsection{Poor structure, governance, and support systems}

The interviewees also revealed that the structure of the SC influences the collaboration between SC partners. Most interviewees mentioned the need for a clearer SC structure and a system which would govern or control the SCs. The current weak supply chain structure not only affects the ability to collaborate and share resources, but it also impacts the overall efficiency of the SC. This quote from a Procurement Manager explains this point:

"The structures are somewhat fragmented to be honest and this affects efficiency. I worked in Europe for several years where the structures on governance are very rigid. So, I think there's a need for a firmer structure that aims to attain high performance for the industry and the economy at large', (Procurement Manager A)

Within the supply chain, interviewees also pointed out that they lack support from manufacturing firms to carry out the numerous activities related to SCs. Therefore, it is not enough to set up a clear SC structure alone, but a support system is needed to promote collaboration between SC partners. This point is explained in an illustrative quote from a Sales Manager:

"Although we have numerous challenges that impact our business, one main problem many of us face is the lack of supporting infrastructures that can increase the likelihood of business success and inter-firm relationships, and this can only come from the top level"' (Sales Manager C)

For SCs, governance and control play a key role in effectively managing businesses involved both at the SC and industrial level. Individual firms need to have an element of governance and structure in place to achieve the objectives of the SCs. This point is further emphasised by a Commercial Manager:

"We need to set up mechanisms that can improve how we operate currently. This new implementation needs to have a long-term vision to develop the manufacturing sector and grow businesses with potential. Many businesses struggle because of the lack of 
systems in place to control and oversee the affairs of the industry effectively" (Commercial Manager E)

\subsection{External environment level issues}

In addition, our interviewees highlighted some external challenges that are out of their control as individual firms, or a SC, which affect their SC collaboration. These important factors are discussed below, based on the insights from the interviewees.

\subsubsection{Safety and security concerns}

Besides the firm level and SC level challenges that influence SC collaboration in Nigeria, respondents also highlighted certain issues out of their own control and part of the external environment they operate, which play a key role. For example, security issues in the environment are a known and prevalent concern which influence several aspects of the SCs for both the manufacturer and the third-party providers. Interviewees grumbled about the high costs associated with the insurance and security of their facilities and manufacturing equipment. There are instances where a delivery truck has been stolen, vandalised, or instances where a member of staff got killed by thieves and armed robbers. Such instances cause major bottlenecks for the manufacturers, the third-parties, and the SC, with delays in the delivery of products. The following illustrative quote by a Supply and Delivery Manager explains this:

"We also have security and safety concerns from warehousing stage up until the delivery stage for retailers and end consumers. We have had issues of burglary and theft from our storage facilities in the past which caused massive delays on product deliveries for our buyers and late payment for our suppliers and affected our collaboration adversely'" (Supply and Delivery Manager F)

This issue was further emphasised particularly for its impact on stock and inventory. It increases the risk of not being able to meet expectations from other SC partners. This issue could also damage the trust level, and overall satisfaction with SC partners. To minimise security issues, SC firms incur high costs, as explained by a Product Delivery Manager:

"Goods and inventory go missing all the time. Our storage facility was raided and set on fire some time ago. We have learnt from that horrible experience and we now pay a lot for security and safety because of the negative impact that it can cause for the supply chain"' (Product Delivery Manager H) 
A Warehouse Manager for a beverage manufacturer also emphasised the impact that these security issues have on their ability to meet demands from the SC due to the huge delays caused which affects collaboration. They explain:

"A few years back, we had an incident that caused enormous delays for our products because one of our main hubs in the country was vandalised by some local unemployed people. A lot of materials were stolen and that took a while to recover from", (Warehouse Manager J)

\subsubsection{Poor transportation infrastructure}

Another important issue that affects the logistical aspect of the collaboration of SC partners in Nigeria is the current state of the transport infrastructure. It is common knowledge that poor infrastructure is a major challenge in Nigeria. Respondents explained that this is a major issue for moving goods from one point to another. This issue affects both the manufacturers and other members of the SC. As a result of the poor transport infrastructure, lead times and delivery schedules are often impacted, which negatively influences the satisfaction level of the affected party in the collaboration. A General Manager explains this in the following quote:

"We have bad transportation linkages, which affects the lead times and scheduling of our deliveries from one point to the other' (General Manager M)

The same point was stressed by a Supply Chain Manager who explained that:

"The transport links can be a big issue. There are also a lot of road accidents that occur every time which cause heavy road traffic, impacting our delivery schedules. We also spend a lot of money on insurance costs due to the high probability of road accidents or vehicle breakdowns" (Supply Chain Manager Q)

There were also concerns about the high costs incurred by regular repairs and the maintenance of trucks due to bad roads. Likewise, interviewees complained that the poor transport systems make it difficult to meet the requirements of the SC partner which affects the relationship quality between them. This point is explained by a Sales and Distribution Manager in the following illustrative quote:

"Our roads are very bad. We spent a lot of money on vehicular repairs and maintenance. I feel this element also affects our ability to meet some of the demands agreed with our supplier', (Distribution Manager $O$ ) 
Likewise, even in situations where supply chain partners have a goal congruence in line with the SC objectives, such joint collaborative objectives are often hindered by factors associated with the poor transport infrastructure highlighted in the following illustrative quote from a Logistics Manager:

"A major challenge for our supply chain is the poor transport network. It costs us a fortune to manage the logistics aspect due to bad roads, regular traffic jams, and severe auto crashes sometimes where people even die. But this is mainly because the roads need fixing, and the transport links need to be upgraded" (Logistics Manager S)

\subsubsection{Energy and power supply crisis}

Our findings indicate that poor energy and power supply across Nigeria creates issues for SCs to collaborate. Many manufacturers are forced to use standby generators to manufacture $F \& B$ products, due to inconsistent power. It is often difficult to use IT systems to share real-time information and to have a collaborative communication. This issue increases face-to-face contact and communication via telephone, which increases costs instead of maximising the potential of IT systems for vendor inventory management and supplier performance management. Even if SCs in Nigeria start to invest in systems that require constant power supply (in the form of a dedicated investment to their relationship), they will still need to consider the costs associated with private power supply. The following illustrative quote by a Plant Manager emphasises this point:

"For many manufacturers and vendors, a great challenge that we all encounter, regardless of the firm size, is lack of constant power/electricity supply' (Plant Manager R)

Our findings highlight the importance of constant energy and power supply for SC collaboration to be productive in Nigeria. We found that many businesses, especially the thirdparty providers who are usually smaller, less powerful, businesses in comparison to the manufacturers really struggle to perform well without regular power supply. Like the manufacturers, most of the third-party providers must spend more money on private electricity to meet the targets of the manufacturers. The following quote from a Distribution Manager explains this:

"It is very difficult to do business and perform excellently without regular power supply. We use generators most of the time and it costs us thousands of Naira monthly", (Distribution Manager T) 
Some third-party providers also struggle to keep goods in conditions deemed suitable for shelf life, due to irregular power supply. The following quote by a Supply Chain Manager illustrates this point:

"The goods we supply down the chain are perishable goods that need to be kept at a certain temperature level to avoid damaging the goods. Nigeria's temperature sometimes goes above 34 degrees and in such a hot climate power supply is key for certain businesses. So, we spend so much on diesel and petrol for our generators", (Supply Chain Manager V)

\subsection{Driving forces of supply chain collaboration}

Based on the three levels of challenges highlighted from the interviews, we found that SC collaboration in Nigeria can develop, or improve, if certain measures are put in place at three subsequent levels; internal, supply chain, and external. They are outlined below.

\subsubsection{Internal firm level}

To manage the highlighted challenges, managers also referred to factors categorised as internal to the focal firms and their SCs. These factors include investing in the training and development of SC personnel to improve their relationship management approach to address some of the behavioural issues and internal ethical issues.

For example, a Supply Executive explained this as follows:

"I feel a lot of training and knowledge is needed on how supply chain collaborations can benefit individual businesses but also the economy at large. When businesses are doing well in a growing economy such as Nigeria, this also benefits the government and living standards" (Supply Executive K)

Our findings also show that SC professionals in Nigeria are urged to undertake regular assessment measures to improve their existing technical know-how on the value of collaboration, and how to deliver value through the entire SC. Thus, focal manufacturing firms should invest in developing their firm representatives (boundary spanners) and their third-party providers through methods such as supplier evaluation and selection, supplier management, and supplier development programmes. This would promote collaboration between F\&B manufacturers and their SC members. A Logistics Manager explains this point:

"Collaboration is often difficult to carry out because some supply chain members hoard critical information to gain competitive advantage over supply chain partners, whom they see as competitors instead of partners. So, a lot of investment needs to be made on training and development' (Logistics Manager L) 
In addition, we found that a regular internal evaluation of SC processes and approaches is important to manage the current challenges and develop SC collaboration for the future. All SC members need to develop a new orientation which encourages collaboration and develops relationship quality along the chain. The following quote by a General Manager considers this point:

"We can talk about many of the obvious issues such as power and bad governance. But many companies also need to re-evaluate themselves as businesses and re-visit their orientation because many businesses operate without the realisation that the customer is of paramount importance", (General Manager M)

\subsubsection{Supply chain level: collaborative activities}

Our findings reveal the importance of collaborative activities in the SC regardless of the challenging context which they operate in. Thus, firms are encouraged to focus on collaborative activities to overcome some of the challenges faced. These collaborative activities (e.g. information sharing could improve visibility by sharing forecast, order information, shipping notes, maintenance plans or even pursue CPFR etc.) can help them resolve issues quickly and manage each other's expectations. Interviewees also mentioned that a lack of coordination is common and has an impact on their SC's higher collaborative effort towards sharing the right type of information between the F\&B manufacturers and third-party. This will aid coordination between SC partners and help minimise risks associated with SCs in emerging markets like Nigeria. The following quote by a Distribution Manager explains this point:

"We often lack coordination, which is due to lack of timely communication. But we also lack systems that would facilitate communication. So, for now, we are trying our best to ensure we have regular meetings with our key supply chain partners, especially the members close to the end-consumers' '(Distribution Manager T)

The same point was also emphasised by a Product Delivery Manager who stated that joint efforts would be crucial in such a complex environment:

"More effort needs to be invested in collaborations, especially in our type of environment, where things rarely work (Product Delivery Manager H), '

In addition, we found that SC members need to invest in innovative ways to develop their collaboration. Such innovative solutions should be context-specific and valid for the environment. This relates to dedicated investments made by SC members and the willingness 
to go the extra mile for the benefit of the relationship. This quote from a Logistics Manager explains this point:

"I think we also need to invest together in innovation and development for our supply chain collaborations to succeed. Many firms in the supply chain rarely invest in people, which affects the overall quality because people are not well trained"' (Logistics Manager S)

Our data indicates that commitment and dedication between the two parties can lead to more willingness to share information, work closely, and solve problems. This can improve trust levels in the long run and develop a strong relationship. The following illustrative quote by a Supply Chain Manager explains this point:

"Our collaboration can also benefit a lot from commitment and dedication that the collaboration can benefit all, trusting other parties more to carry out their duties without any thoughts that we will be cheated in some way can help the collaboration" (Supply Chain Manager V)

\subsubsection{External: government support, investment, and reforms}

In addition to the internal and SC level solutions, interviewees also emphasised the need for an external support system which would develop a suitable business environment. Some respondents stated that the government has a huge role to play in dealing with issues facing SCs in Nigeria. Some issues cannot be tackled by a focal firm (manufacturer) or SC member. These issues include, but are not limited to, fixing the bad roads and transport links, reviving the Nigerian railway for commercial use, fixing the supply of electricity, creating reforms to improve ethical behaviours, introducing sanctions at the national level for fraudulent practices, etc. Thus, there is a need for stronger governmental support to resolve some of these challenges. These recommendations were emphasised by a Commercial Manager who gave the following quote:

"The weak corporate supply chain governance can be dealt with by introducing rules and regulations that industry professionals and companies can abide by. We have some structures in place, but they are too weak in my opinion and they create avenues for different practices that are, in the long-run, damaging to the longevity of collaborations"' (Commercial Manager E)

Likewise, interviewees stressed that these government-level investments should have a focus on enabling business collaboration and inter-firm trade by concentrating on important aspects such as involving stakeholders in the reformation process, industry level engagement, resolving 
issues of power failure, which would foster technology expansion. For example, a Sales and Distribution Manager explained that:

"There needs to be an environment that enables collaboration through investments in people, industry, technology, power, security, infrastructure and regulatory bodies (Distribution Manager O)'”.

Overall, external-level support from the Nigerian government can help to minimise some of the unethical, corrupt, fraudulent acts, and negative use of power that are often exhibited in the business environment through the implementation of the revealed reforms.

\section{Insert Table 2 about here: Interview findings}

\section{Discussion}

This study set out to investigate the ways in which driving forces and restraining forces enhance $\mathrm{SC}$ collaboration in the context of a fast-growing economy in Africa (i.e. Nigeria) from the force field theory perspective. It examined the particularities of internal issues and external issues that impact on SC collaboration and the strategies to overcome these.

We found that the challenges faced by many SCs in emerging markets like Nigeria are divided into three categories, which are internal to the individual firms, at the SC level, and at the external environment level. These findings are new and different from the challenges found by past studies such as make or buy decisions, who manages the SC, or the scope of managed SC activities (e.g. Ballou et al., 2000; Beth et al., 2003; Storey et al., 2006; Christopher et al., 2016; Lambert and Enz, 2017). However, they are context-specific and like past studies conducted in the African setting (e.g. Hamisi, 2011; Adebayo, 2012; Ambe and BadenhorstWeiss, 2012). Thus, in line with the force field theory, we were able to unravel the restraining and driving forces of collaboration between SC partners in an emerging market like Nigeria. These forces are linked to three levels which are explained in the table below:

Insert Table 3 about here: Categories of restraining and driving forces of SC collaboration in an emerging market 


\subsection{Restraining forces of supply chain collaboration}

At the internal firm level, our findings lay emphasis on the relationship between SC collaboration and individual behavioural change. Extending the current knowledge on SCM in Africa and the associated challenges, our research shows that people and their behavioural issues influence the prospects of a solid collaboration between SC partners. This is in support of the existing literature, which has recognised the role of people and human behaviour in SCM (Schorsch et al., 2017; Gligor et al., 2019). However, this issue is fundamental in emerging markets due to some of the different cultures and individual beliefs held by people (Aluko, 2003). This issue is intertwined with another theme found in this research called internal ethical issues. For example, some businesses operate based on personal ties and "Guanxi' type of interactions which have pros and cons (Fan and Stevenson, 2018; Lu et al., 2018; Xing et al., 2020). For the cons, there are situations where one SC partner who was selected on personal ties and not on merit will do as they please and impact collaboration between the two parties. Subsequently, it becomes difficult to sanction such parties due to the back-door nature of the relationships between key individuals in each party. For example, this insight adds to the debate around the role of Guanxi networks in SCs (Lee and Humphreys, 2007; Cheng et al., 2012; Cai and Yang, 2017; Butt et al., 2020), but from a negative perspective. Our data further suggests that fraudulent activities such as bribery, corruption, insider abuse etc. influence SC collaboration. This is another unique finding which is specific to emerging markets but has not appeared repeatedly in the pertinent literature on SCM. Though past studies (e.g. Luo, 2006; Svensson and Bååth, 2008; Eriksson and Svensson, 2016) have considered ethical issues and social responsibility in SCs, they neglected issues such as fraud in the SC context. This is, however, understandable considering that most studies on SCM have been done outside the African setting, where such concerns do not often come up. Thus, we add to the current understanding in the literature by revealing that hidden ethical issues can affect SC collaboration in emerging markets. These identified internal issues add to the uniqueness of emerging markets like Nigeria, and help explain why collaboration between SC partners is not as straightforward in comparison to developed markets.

This research extends the current understanding on SC collaboration by revealing how FFT enables changes in various SC collaboration networks structure and systems e.g. reward systems, reporting relationships, and the design of SC collaboration. The literature has recognised the influence of SC collaboration on the development of synergies among SC partners by facilitating joint planning and promoting the exchange of data (Whipple and 
Russell, 2007). Collaborative activities such as information-sharing, joint development of strategic plans, and dedicated investments have also been recognised as key practices for improving SC performance and relationship development prospects (Simatupang and Sridharan, 2008; Cao et al., 2010; Nyaga et al., 2010). Although SC collaboration and collaborative activities offer a number of benefits to supply chain members such as flexibility and reduced lead times (Kache and Seuring, 2014), it may be difficult to attain a high level of collaboration in a context where the environmental conditions are unique. The FFT suggests that environmental conditions are driving forces upon which partners could exert their will to gain competitive advantage.

At the SC level, we find that there is a weak IT infrastructure to enable key SC collaborative activities, particularly relating to the exchange of data and communication. This issue is a general problem with most firms in developing countries, which affects other branches of collaboration such as knowledge sharing, decision synchronisation, collaborative planning, and adaptive processes. While past studies (e.g. Gunasekaran and Ngai, 2004) have found that collaboration in SCs is increased by information systems, our study only shows that unavailability of such systems creates issues. Likewise, we found that SC restraining forces in emerging markets like Nigeria are also related to poor structure, governance, and control systems. Most SCs struggle due to the poor design and mapping of the SC. This also relates to governance and responsibility in the SC with questions such as who is responsible for what, what mechanisms are in place to revise the fragmented structure. These issues are in line with the findings of Storey et al. (2006) who found similar results such as "who is managing the supply chain'. We thus add to the literature by stressing the importance of structure, governance, and support systems as enablers or antecedents of SC collaboration as past studies (e.g. Min et al., 2005; Cao et al., 2010; Zhang and Cao, 2018) have not considered this in their model. Though these issues may be prevalent in developed countries, they impact SC collaboration in developing countries, particularly in an emerging market such as Nigeria, where a rigid structure is absent due to the nature of the environment.

At the external environment level, the results of our study highlight important factors that are not often included in the discussion about SC collaboration. We found that factors related to the Nigerian environment (institutional) play a major role in the efficiency and effectiveness of collaboration amongst SC members. These factors, such as poor transport infrastructure e.g. bad roads, regular power cuts, security issues etc, disrupt the flow of collaborative activities between SC partners. For example, the literature (e.g. Gunasekaran and Ngai, 2004; Aronsson 
et al., 2005; Prajogo and Olhager, 2012; DeGroote and Marx, 2013; Gunasekaran et al., 2017) has stressed the need and importance of IT systems and big data analytics in integrating and developing SC collaboration. Some of the restraining forces of SC collaboration revealed in this study are similar to those identified in other developed and developing markets such as ethical climate and culture (Blome and Paulraj 2013; Simangunsong et al., 2016), social capital, justice, and technology (Wu and Chiu, 2018), and human behaviour (Tsanos and Konstantinos, 2016). However, our research found that restraining forces at the external environmental level, such as safety and security concerns, energy and power supply crises, poor transportation infrastructure, are dominant in emergent markets because of the uniqueness of the environment. For example, in Nigeria, power cuts and poor electricity supply can hinder the efficient flow of data and running of such systems. The dominance of outdated and non-integrated technologies in the SCs in Nigeria also increases costs, as firms tend to spend a lot more on undertaking duties in such a complex environment. Thus, our research contributes to the SCM literature, especially in emerging markets, as it clearly shows some factors which are not so common when evaluating SCs in developed countries, but play a crucial role for SCs in emerging economies.

\subsection{Driving forces of supply chain collaboration}

Our findings also highlight the driving forces associated with SC collaboration in emerging markets. These drivers are divided into three subsequent levels; internal, SC, and external environmental level, related to the associated restraining forces identified.

At the internal level, our findings suggest that focal firms need to pay close attention to internal activities and practices that can develop the firm's representatives in the SC to reduce behavioural issues and issues related to unethical practice. Individual firms need to take some responsibility in managing their own processes in the first instance by undertaking regular process evaluations to determine what works and does not work. This may also include introducing performance measures for SC staff and surveys to improve relationship management approaches. Likewise, a lot of investment in training and development is required to improve the value of collaboration (from an interpersonal perspective), as this would have a positive impact on SC collaboration climate.

At the SC level, in line with past studies (Cao et al., 2010; Cao and Zhang, 2011), our findings reveal that collaborative activities such as joint meetings, commitment to the 
relationship, dedicated investment to the relationship, can all improve the collaboration between SC partners. SC partners are thus encouraged to pay close attention to collaborative activities to develop their SC relationship. Notwithstanding this, whether these collaborative activities will improve collaboration in Nigerian SCs may depend upon the context. Thus, whether the context allows such collaborative activities to have an impact in the first place is a question that requires further deliberation.

At the environmental level, our findings indicate that government support, investment and reforms can help the general environment and SCs function effectively and efficiently. This issue is important since many businesses require a suitable environment to function. This finding is also unique because government and institutional level support initiatives are not regularly discussed in SC studies. Thus, this insight adds to the debate in the literature (e.g. Herczeg et al., 2018; Pakdeechoho and Sukhotu, 2018), regarding the role of governments as support systems for businesses and SCs based on several initiatives and legislation that could be introduced to develop collaboration between SC partners.

Furthermore, there are driving forces of SC collaboration which are common to both developed and emerging markets such as collaborative activities at the SC level (Wiengarten et al., 2010). However, our study found that some driving forces such as investment in training and development, governmental support etc are crucial to the success of SC collaboration in emerging markets.

Insert Figure 2 about here: Restraining forces and driving forces of SC collaboration in an emerging market

\section{Conclusion}

To date, research on SC collaboration in emerging markets is at a nascent stage (Fawcett et al., 2008; Soosay and Hyland, 2015; Orji et al., 2019). This study contributes to the pertinent literature by expanding the current knowledge about SC collaboration to emerging markets. The key objective of this study was to provide an understanding of the ways in which restraining forces and driving forces impact SC collaboration in emerging markets. The findings show that to fully understand SC collaboration, other contexts need to be included in the debate. We discuss the implications of our results for theory and practice below. 


\subsection{Theoretical contributions}

This research provides valuable contributions to the SCM literature by offering rare empirical evidence on the factors that may restrain and drive collaboration between SC partners in an emerging market. With the help of the FFT, this research adds to the literature by proposing a comprehensive framework which categorises the restraining and driving forces of SC collaboration into three distinct levels: internal, supply chain, and external environment level. This study has highlighted the significance of individual skills, values, and behaviour in developing a strong SC collaboration. Likewise, it has revealed how those who work in each partner firm (boundary spanners) can be part of the restraining forces, and how various SC network structures and systems can directly impact SC collaboration. These new perspectives contribute to the findings of past studies regarding the complexity of collaboration in SC networks (e.g., Nyaga et al., 2013; Cao et al., 2015; Fawcett et al., 2015; Lambert and Enz, 2017; Huang et al., 2020). Similarly, the findings contribute to previous studies (e.g., Lambert and Schwieterman, 2012; Huang et al., 2014; Schorsch et al., 2017; Dekker et al., 2019) regarding some of the approaches for managing SCs in today's complex business environment. For example, investing in SC technologies, supplier relationship management (SRM), and ethical approaches may lead to long-term collaborative benefits such as minimal cost of information sharing, innovation exchange and creation of value, reduction of price from areas of the SC, etc. Such approaches may be useful for improving SC collaboration in emerging markets.

In addition, most studies conducted on SC collaboration are in the context of developed countries (Wiengarten et al., 2010; Soosay and Hyland, 2015; Vlachos and Dyra, 2020). The characteristics of developed countries are different from emerging markets and as a result, some of the recommendations for SC collaboration may not be applicable in emerging markets (Arora and Hartley, 2020). Thus, our study supplements the inadequacy of research on SC collaboration in the context of emerging markets. Moreover, our research elaborates the findings of existing studies on SC collaboration in emerging markets (e.g., Cadilhon and Fearne 2005; Vieira et al., 2009; Bezuidenhout et al., 2012; Kumar et al., 2017; Shukor et al., 2020), by determining how the identified restraining and driving forces influence SCs. This is vital due to the contextual realities of emerging markets, such as the lack of a stable political environment, weak formal structures, fragmented infrastructural systems, transparency issues, corruption etc, which adversely affect suppliers and buyers in the SC. Finally, our framework 
may also serve as a useful theoretical guide for future empirical SC collaboration studies in emerging markets.

\subsection{Practical implications}

This research has several practical implications. First, the findings challenge the current SCM framework in emerging markets like Nigeria, which our study reveals is currently fragmented, considering the nature of buyer-supplier relations, and the unique manufacturer and third-party relationship in the F\&B manufacturing sector. Such resurgence can improve business-tobusiness dealings, leading to effective SC collaboration initiatives and practice. This can lead to a win-win scenario for all SC partners rather than the current one-sided, power-imbalanced, and multi-faceted condition.

Second, this paper has provided some valuable insights for SCM managers to rethink their approach to collaboration. The findings show that for SC collaboration to work, managers need to pay close attention to factors internal to their focal firm, at the SC level, and elements in the external setting. At the internal level, SCM practitioners will need to invest in people to ensure that their proficiency is up to the standard acceptable SCM practice. At the SC level, practitioners need to evaluate the current processes which facilitate inter-firm dealings with current and potential SCs, as it is currently not fit for purpose (Didia and Nwokah 2015). This step would foster collaborative initiatives and improve joint relationship working.

At the external environmental level, the findings challenge regulatory authorities in emerging markets to understand that weaknesses in SCs are partially due to the poor state of infrastructure, weak policies, minimal investment etc. (Okonjo-Iweala and Osafo-Kwaako, 2007; Okafor, 2008). Thus, it is imperative for policy makers to invest heavily in transforming the current structure and monitor the change for performance improvement in the sector. Our findings have further illustrated that context is significant for a better understanding of SCM and SC collaboration challenges (Ugonna et al., 2015). Therefore, a detailed understanding of contextual factors can help in illuminating and rethinking the management of SCs and collaborative relationships in emerging markets.

Overall, based on the practical contributions of our research, the following areas are crucial:

1. Policy level (business policy and infrastructural development) 
2. Education level (inclusion of SCM in the educational curriculum of business schools to enhance the knowledge base and skills of future talents in the field of $\mathrm{SCM})$

3. Individual practitioner level (short courses to develop skill gaps for continuous professional development through Professional Institutes (e.g., CIPS, CILT, ISM, etc.)

4. Supply chain level (stakeholders joint working group, annual conferences etc.).

The findings of this research show that SC collaboration and general SCM in emerging markets like Nigeria will need to improve rapidly to be able to compete internationally, especially because today's market is moving towards supply chain vs supply chain competition. This knowledge is also valuable for multinational corporations looking to expand their supply network to developing markets and Africa.

\subsection{Limitations and further research}

Notwithstanding the insights offered in this study, it is potentially limited due to its context, the number of organisations that participated (a total of twenty-two), and the purposive sampling method applied (based on selected interviewees). The exploratory nature of this research may also be limiting, such an approach may hinder an in-depth examination (Saunders et al., 2009). Likewise, the qualitative nature of this study also restricts the generalisability of its results. The industry ( $F \& B$ manufacturing sector) considered in this study may be another limiting factor. But, given the significance of this sector for Nigeria's GDP, addressing SC collaboration challenges offers significant benefits for inter-firm trading in emerging markets like Nigeria. Equally, the issues highlighted here create opportunities for further studies to dig deeper into the concept of SC collaboration and its associated phenomena in emerging markets.

Further research could be done to enable generalisation by employing a quantitative method as well as a comparative research to expand knowledge and insights beyond what is already known (Silverman, 2006). Future research adopting other theoretical lenses and approaches to develop the nascent SC collaboration concept from different positions in developing countries is suggested. They may find other unique contextual factors which may influence SC collaboration such as industry features, conflicts, culture, and institutional norms. 


\section{References}

Adebanjo, D., Ojadi, F., Laosirihongthong, T. and Tickle, M. (2013), “A case study of supplier selection in developing economies: a perspective on institutional theory and corporate social responsibility', Supply Chain Management: An International Journal, Vol. 18 No. 5, pp. 553-566.

Adebayo, I.T. (2012), "Supply Chain Management (SCM) Practices in Nigeria Today: Impact on SCM Performance', European Journal of Business and Social Sciences, Vol. 18 No. 6, pp. 107-115.

Aluko, M. A. O. (2003), "The impact of culture on organizational performance in selected textile firms in Nigeria', Nordic Journal of African Studies, Vol. 12 No. 2, pp. 16-16.

Ambe, I. M., and Badenhorst-Weiss, J. A. (2012), "Supply chain management challenges in the South African public sector', African Journal of Business Management, Vol. 6 No. 44, pp. 11003.

Anderson, E. and Weitz, B. (1992), "The use of pledges to build and sustain commitment in distribution channels", Journal of Marketing Research, Vol. 29 No. 1, pp. 18-34.

Aronsson, H., Auramo, J., Kauremaa, J., and Tanskanen, K. (2005), “'Benefits of IT in supply chain management: an explorative study of progressive companies", International Journal of Physical Distribution \& Logistics Management, Vol. 35 No. 2, pp. 82-100.

Arora, A.S. and Hartley, N. (2020), "Emerging research themes in global value chains", International Journal of Emerging Markets, Vol. 15 No. 1, pp. 1-3.

Babarinde, O. A. (2009), "Africa is open for business: A continent on the move", Thunderbird International Business Review, Vol 51. No. 4, pp. 319-328.

Ballou, R. H., Gilbert, S. M., and Mukherjee, A. (2000), "New managerial challenges from supply chain opportunities', Industrial Marketing Management, Vol 29 No. 1, pp. 718.

Barratt, M. (2004), "Understanding the meaning of collaboration in the supply chain", Supply Chain Management: An International Journal, Vol. 9 No. 1, pp. 30-42.

Barratt, M., Choi, T. Y., and Li, M. (2011), "Qualitative case studies in operations management: Trends, research outcomes, and future research implications', Journal of Operations Management, Vol. 29 No. 4, pp. 329-342.

Beth, S., Burt, D. N., Copacino, W., Gopal, C., Lee, H. L., Lynch, R. P., and Morris, S. (2003), "Supply chain challenges. Building relationships", Harvard Business Review, Vol. 81 No. 7, pp. 64-73.

Bezuidenhout, C. N., Bodhanya, S. and Brenchley, L. (2012), "An analysis of collaboration in a sugarcane production and processing supply chain", British Food Journal, Vol. 114 No. 6, pp. 880-895.

Bhakoo, V., Singh, P. and Sohal, A. (2012), "Collaborative management of inventory in Australian hospital supply chains: practices and issues", Supply Chain Management: An International Journal, Vol. 17 No. 2, pp. 217-230.

Blome, C. and Paulraj, A. (2013). Ethical climate and purchasing social responsibility: A benevolence focus. Journal of Business Ethics, Vol. 116 No. 3, pp.567-585.

Brito, R. P. and Miguel, P. L. (2017), "Power, governance, and value in collaboration: Differences between buyer and supplier perspectives', Journal of Supply Chain Management, Vol. 53 No. 2, pp. 61-87.

Buijs, P. and Wortmann, J.C. (2014), “Joint operational decision-making in collaborative transportation networks: the role of IT', Supply Chain Management: An International Journal, Vol. 19 No. 2, pp. 200-210.

Busse, C., Schleper, M.C., Niu, M. and Wagner, S.M. (2016), "Supplier development for sustainability: contextual barriers in global supply chains", International Journal of Physical Distribution \& Logistics Management, Vol. 46 No. 5, pp. 442-468. 
Butt, A.S., Shah, S.H.H. and Sheikh, A.Z. (2020), "Is guanxi important in a buyer-supplier relationship? Case of Chinese logistics industry", Journal of Asia Business Studies, Vol. 14 No. 1, pp. 1-14.

Cai, S., Jun, M. and Yang, Z. (2017), “The effects of boundary spanners' personal relationships on interfirm collaboration and conflict: a study of the role of guanxi in China', Journal of Supply Chain Management, Vol. 53 No. 3, pp. 19-40.

Cai, S., Goh, M., De Souza, R., and Li, G. (2013), “Knowledge sharing in collaborative supply chains: twin effects of trust and power', International Journal of Production Research, Vol. 51 No. 7, pp. 2060-2076.

Cannon, J.P. and Perreault Jr, W.D. (1999), "Buyer-seller relationships in business markets", Journal of Marketing Research, Vol. 36 No. 4, pp. 439-460.

Cao, M., Vonderembse, M., Zhang, Q. and Ragu-Nathan, T.S. (2010), "Supply chain collaboration: conceptualisation and instrument development", International Journal of Production Research, Vol. 48 No. 22, pp. 6613-6635.

Cao, M. and Zhang, Q. (2011), "Supply chain collaboration: Impact on collaborative advantage and firm performance', Journal of Operations Management, Vol. 29 No. 3, pp. 163-180.

Central Intelligence Agency (2020), “The World Fact Book: Africa, Nigeria', Available at: https://www.cia.gov/library/publications/the-world-factbook/geos/ni.html. [Assessed on; $10^{\text {th }}$ August 20120].

Chen, L., Zhao, X., Tang, O., Price, L., Zhang, S. and Zhu, W., (2017), "Supply chain collaboration for sustainability: A literature review and future research agenda', International Journal of Production Economics, Vol. 194, pp.73-87.

Cheng, T. C. E., Yip, F. K., and Yeung, A. C. L. (2012), "Supply risk management via guanxi in the Chinese business context: The buyer's perspective", International Journal of Production Economics, Vol. 139 No. 1, pp. 3-13.

Christopher, M., Harrison, A., and van Hoek, R. (2016), Creating the agile supply chain: issues and challenges, In Developments in logistics and supply chain management, Palgrave Macmillan, London, pp. 61-68.

Chu, Z. and Wang, Q. (2012), "Drivers of Relationship Quality in Logistics Outsourcing in China', Journal of Supply Chain Management, Vol. 48 No. 3, pp. 78-96.

Corbin, J. M. and Strauss, A. (1990), "Grounded theory research: Procedures, canons, and evaluative criteria', Qualitative Sociology, Vol. 13 No. 1, pp. 3-21.

Creswell, J. W., and Poth, C. N. (2016). Qualitative inquiry and research design: Choosing among five approaches. Sage publications, London.

DeGroote, S. E., and Marx, T. G. (2013), "The impact of IT on supply chain agility and firm performance: An empirical investigation', International Journal of Information Management, Vol. 33 No. 6, pp. 909-916.

Dekker, H., Donada, C., Mothe, C., and Nogatchewsky, G. (2019), "Boundary spanner relational behavior and inter-organizational control in supply chain relationships", Industrial Marketing Management, Vol. 77, pp. 143-154.

Didia, J. U. D., and Nwokah, N. G. (2015), "Supply chain integration and business performance in the telecommunication industry in Nigeria', International Journal of Supply Chain Management, Vol. 4 No. 2, pp. 81-89.

Easterby-Smith, M., Thorpe, R., and Jackson, P. R. (2012), Management research, 4th Edition, Sage, London.

Edmondson, A. C. and McManus, S. E. (2007), "Methodological fit in management field research', Academy of Management Review, Vol. 32 No. 4, pp. 1246-1264.

Eisenhardt, K.M. (1989), "Building theories from case study research", The Academy of Management Review, Vol. 14 No. 4, pp. 532-550. 
Eisenhardt, K.M. and Graebner, M.E. (2007), "Theory building from cases: opportunities and challenges", Academy of Management Journal, Vol. 50 No. 1, pp. 25-32

Ellram, L.M. and Cooper, M.C. (1990), "Supply chain management, partnership and the shipper - Third party relationship", The International Journal of Logistics Management, Vol. 1 No. 2, pp. 1-10.

Eriksson, D., and Svensson, G. (2016), “The process of responsibility, decoupling point, and disengagement of moral and social responsibility in supply chains: Empirical findings and prescriptive thoughts"', Journal of Business Ethics, Vol. 134 No. 2, pp. 281-298.

Fawcett, S.E., Magnan, G.M. and McCarter, M.W. (2008), "Benefits, barriers and bridges to effective supply chain management", Supply Chain Management: An International Journal, Vol. 13 No. 1, pp. 35-48.

Fawcett, S.E., Magnan, G.M. and Fawcett, A.M. (2010), "Mitigating resisting forces to achieve the collaboration-enabled supply chain", Benchmarking: An International Journal, Vol. 17 No. 2, pp. 269-293.

Fawcett, S.E., Fawcett, A.M., Watson, B.J. and Magnan, G.M. (2012), "Peeking inside the black box: toward an understanding of supply chain collaboration dynamics", Journal of Supply Chain Management, Vol. 48 No. 1, pp. 44-72.

Fawcett, S.E., McCarter, M.W., Fawcett, A.M., Webb, G.S. and Magnan, G.M. (2015), "Why supply chain collaboration fails: the socio-structural view of resistance to relational strategies', Supply Chain Management: An International Journal, Vol. 20 No. 6, pp. 648-663.

Fan, Y. and Stevenson, M. (2018), "Reading on and between the lines: risk identification in collaborative and adversarial buyer-supplier relationship", Supply Chain Management: An International Journal, Vol. 23 No. 4, pp. 351-376.

Flynn, B., Huang, X. and Zhao, X. (2014), "Supply Chain Management in Emerging Markets: Critical Research Issues. Journal of Supply Chain Management, Vol. 51 No. 1, pp.3-4.

Gado, N. D. (2015), "The impact of the Nigerian business environment on company performance: a case of 20 most capitalized companies in Nigeria", International Journal of Business and Management Review, Vol. 3 No. 4, pp. 36-48.

Ganesan, S. (1994), 'Determinants of Long-Term Orientation in Buyer-Seller Relationships', Journal of Marketing, Vol. 58 No. 2, pp. 1-19.

Gehman, J., Glaser, V.L., Eisenhardt, K.M., Gioia, D., Langley, A. and Corley, K.G. (2018), "Finding theory-method fit: a comparison of three qualitative approaches to theory building", Journal of Management Inquiry, Vol. 27 No. 3, pp.

Gligor, D., Bozkurt, S., Russo, I. and Omar, A. (2019), "A look into the past and future: theories within supply chain management, marketing and management', Supply Chain Management: An International Journal, Vol. 24 No. 1, pp. 170-186.

Gunasekaran, A., Papadopoulos, T., Dubey, R., Wamba, S. F., Childe, S. J., Hazen, B., and Akter, S. (2017), "Big data and predictive analytics for supply chain and organizational performance', Journal of Business Research, Vol. 70, pp. 308-317.

Gunasekaran, A., and Ngai, E. W. (2004), "Information systems in supply chain integration and management". European Journal of Operational Research, Vol. 159 No. 2, pp. 269-295.

Hamisi, S., (2011), "Challenges and opportunities of Tanzanian SMEs in adapting supply chain management', African Journal of Business Management, Vol. 5 No. 4, pp. 1266.

Heide, J.B. and John, G. (1990), "Alliances in industrial purchasing: The determinants of joint action in buyer-supplier relationships", Journal of Marketing Research, Vol. 27 No. 1, pp. 24-36. 
Herczeg, G., Akkerman, R., and Hauschild, M. Z. (2018), "Supply chain collaboration in industrial symbiosis networks", Journal of Cleaner Production, Vol. 171, pp. 10581067.

Huang, M. C., Cheng, H. L. and Tseng, C. Y. (2014), "Reexamining the direct and interactive effects of governance mechanisms upon buyer-supplier cooperative performance", Industrial Marketing Management, Vol. 43 No. 4, pp. 704-716.

Huang, Y., Han, W. and Macbeth, D.K. (2020), "The complexity of collaboration in supply chain networks", Supply Chain Management: An International Journal, Vol. 25 No. 3, pp. 393-410.

International Monetary Fund (2019), "World Economic Outlook Database", Available at: http://www.imf.org/en/publications/weo. [Assessed on 11th October 2019].

Jap, S.D. and Ganesan, S. (2000), "Control mechanisms and the relationship life cycle: Implications for safeguarding specific investments and developing commitment', Journal of Marketing Research, Vol. 37 No. 2, pp. 227-245.

Kache, F. and Seuring, S. (2014), "Linking collaboration and integration to risk and performance in supply chains via a review of literature review', Supply Chain Management: An International Journal, Vol. 19 No. 5/6, pp. 664-682.

Katsikeas, C.S., Skarmeas, D. and Bello, D.C., (2009), "Developing successful trust-based international exchange relationships", Journal of International Business Studies, Vol. 40 No. 1, pp. 132-155.

Kembro, J. and Näslund, D. (2014), "Information sharing in supply chains, myth or reality? A critical analysis of empirical literature', International Journal of Physical Distribution and Logistics Management, Vol. 44 No. 3, pp. 179-200.

Ketokivi, M. and Choi, T. (2014), "Renaissance of case research as a scientific method", Journal of Operations Management, Vol. 32 No. 5, pp. 232-240.

Koçoğlu, İ., İmamoğlu, S.Z., İnce, H. and Keskin, H. (2011), "The effect of supply chain integration on information sharing: Enhancing the supply chain performance", Procedia-Social and Behavioral Sciences, Vol. 24, pp. 1630-1649.

Kohli, A. S., and Jensen, J. B. (2010), "Assessing effectiveness of supply chain collaboration: an empirical study', Supply Chain Forum: An International Journal, Vol. 11 No. 2, pp. 2-16.

Kumar, V., Verma, P., Sharma, R.R.K. and Khan, A.F. (2017), "Conquering in emerging markets: critical success factors to enhance supply chain performance", Benchmarking: An International Journal, Vol. 24 No. 3, pp. 570-593.

Kwon, I.G., and Suh, T. (2005), "Trust, commitment and relationships in supply chain management: a path analysis', Supply Chain Management: An International Journal, Vol. 10 No. 1, pp. 26-33.

Lalonde, B.J. (1998), "Building a supply chain relationship", Supply Chain Management Review, Vol. 2 No. 2, pp. 7-8.

Lambert, D.M. and Schwieterman, M.A. (2012), "Supplier relationship management as a macro business process", Supply Chain Management: An International Journal, Vol. 17 No. 3, pp. 337-352.

Lambert, D. M., and Enz, M. G. (2017), "Issues in supply chain management: Progress and potential', Industrial Marketing Management, Vol. 62, pp. 1-16.

Lee, T. W., Mitchell, T. R., and Sablynski, C. J. (1999), “Qualitative research in organizational and vocational psychology, 1979-1999', Journal of Vocational Behavior', Vol. 55 No. 2, pp. 161-187.

Lee, P. K., and Humphreys, P. K. (2007), "The role of Guanxi in supply management practices', International Journal of Production Economics, Vol. 106 No. 2, pp. 450467. 
Lewin, K. (1951), Field Theory in Social Science, Harper Row, London.

Li, J., Sikora, R., Shaw, M.J. and Tan, G.W. (2006), "A strategic analysis of inter organizational information sharing', Decision Support Systems, Vol. 42 No.1, pp. 251266.

Li, S. and Lin, B. (2006), "Accessing information sharing and information quality in supply chain management", Decision Support Systems, Vol. 42 No. 3, pp. 1641-1656.

Lincoln, Y.S. and Guba, E.G. (2013), The Constructivist Credo, Left Coast Press, CA.

Liu, W., Yan, X., Si, C., Xie, D. and Wang, J. (2020), "Effect of buyer-supplier supply chain strategic collaboration on operating performance: evidence from Chinese companies", Supply Chain Management: An International Journal, Vol. 25 No. 6, pp. 823-839.

Lu, H.E., Potter, A., Sanchez Rodrigues, V. and Walker, H. (2018), “Exploring sustainable supply chain management: a social network perspective', Supply Chain Management: An International Journal, Vol. 23 No. 4, pp. 257-277.

Luo, Y. (2006), “'Opportunism in Inter-firm Exchanges in Emerging Markets', Management and Organization Review, Vol. 2 No. 1, pp. 121-147.

Mabey, C., Mayon-White, B., and Mayon-White, W. M. (1993). Managing change, Sage, Wiltshire.

Manuj, I. and Mentzer, J.T. (2008), "Global supply chain risk management strategies", International Journal of Physical Distribution and Logistics Management, Vol. 38 No. 3, pp. 192-223.

Matopoulos, A., Vlachopoulou, M., Manthou, V. and Manos, B. (2007), "A conceptual framework for supply chain collaboration: empirical evidence from the agri-food industry", Supply Chain Management: An International Journal, Vol. 12 No. 3, pp. 177-86.

Mccarter, M.W. and Northcraft, G.B. (2007), "Happy together? Insights and implications of viewing managed supply chains as a social dilemma", Journal of Operations Management, Vol. 25 No. 2, pp. 498-511.

Meredith, J. (1998), "Building operations management theory through case and field research', Journal of Operations Management, Vol. 16 No. 4, pp. 441-454.

Merriam, S. B., and Tisdell, E. J. (2015), Qualitative research: A guide to design and implementation. John Wiley \& Sons.

Merriam, S. B., and Grenier, R. S. (2019), Qualitative research in practice: Examples for discussion and analysis. John Wiley \& Sons.

Miles, M.B. and Huberman, A.M. (1994), Qualitative Data Analysis: An Expanded Sourcebook, Sage Publications, Thousand Oaks, London.

Min, S., Roath, A.S., Daugherty, P.J., Genchev, S.E., Chen, H., Arndt, A.D. and Glenn Richey, R. (2005), 'Supply chain collaboration: what's happening?', The International Journal of Logistics Management, Vol. 16 No. 2, pp. 237-256.

Moberg, C.R., Cutler, B.D., Gross, A. and Speh, T.W. (2002), "Identifying antecedents of information exchange within supply chains', International Journal of Physical Distribution and Logistics Management, Vol. 32 No.9, pp. 755-770.

Muogboh, O.S. and Ojadi, F. (2018), "Indigenous Logistics and Supply Chain Management Practice in Africa', Indigenous Management Practices in Africa (Advanced Series in Management, Vol. 20), Emerald Publishing Limited, pp. 47-70.

Njoku, C. (2019), "Here are 5 security challenges Nigeria's leader must tackle', World Economic Forum. Available online at: https://www.weforum.org/agenda/2019/02/5security-challenges-facing-nigerias-leadership/. Accessed on $\left[15^{\text {th }}\right.$ November 2019].

Nyaga, G.N., Whipple, J.M. and Lynch, D.F. (2010), "Examining supply chain relationships: do buyer and supplier perspectives on collaborative relationships differ?', Journal of Operations Management, Vol. 28 No. 2, pp. 101-114. 
Nyaga, G. N., Lynch, D. F., Marshall, D., and Ambrose, E. (2013), "Power asymmetry, adaptation and collaboration in dyadic relationships involving a powerful partner', Journal of Supply Chain Management, Vol. 49 No. 3, pp. 42-65.

Orji, I. J., Kusi-Sarpong, S., Gupta, H., and Okwu, M. (2019), 'Evaluating challenges to implementing eco-innovation for freight logistics sustainability in Nigeria", Transportation Research Part A: Policy and Practice, Vol. 129, pp. 288305.

Oyedijo, A. (2011), "Gaining a Competitive Marketing Advantage in an Era of Globalization: Some Challenges for Indigenous Firms in Developing Countries', The Nigerian Journal, Vol. 5 No. 1, pp. 45-61.

Ojadi, F., Tickle, M., Adebanjo, D., Laosirihongthong, T., and Boon-itt, S. (2017), "Supplier qualification for high-value goods and services in Nigeria: a comparison of qualified and non-qualified suppliers', International Journal of Logistics Research and Applications, Vol. 20 No.3, pp. 201-216.

Okafor, E. E. (2008), "Development crisis of power supply and implications for industrial sector in Nigeria", Studies of Tribes and Tribals, Vol. 6 No. 2, pp. 83-92.

Okonjo-Iweala, N., and Osafo-Kwaako, P. (2007), "Nigeria's economic reforms: Progress and challenges”, Brookings Global Economy and Development Working Paper, pp.6.

Patton, M.Q. (2015), Qualitative Research \& Evaluation Methods: Integrating Theory and Practice, 4th ed., Utilization Focused Evaluation, Saint Paul, MN.

Pakdeechoho, N. and Sukhotu, V. (2018), "Sustainable supply chain collaboration: incentives in emerging economies', Journal of Manufacturing Technology Management, Vol. 29 No. 2, pp.273-294.

Pimentel Claro, D., Borin de Oliveira Claro, P. and Hagelaar, G. (2006), "Coordinating collaborative joint efforts with suppliers: the effects of trust, transaction specific investment and information network in the Dutch flower industry", Supply Chain Management: An International Journal, Vol. 11 No. 3, pp. 216-224.

Panahifar, F., Byrne, P.J., Salam, M.A. and Heavey, C. (2018), "Supply chain collaboration and firm's performance: The critical role of information sharing and trust", Journal of Enterprise Information Management, Vol. 31 No. 3, pp. 358-379.

Pradabwong, J., Braziotis, C., Tannock, J.D.T. and Pawar, K.S. (2017), "Business process management and supply chain collaboration: effects on performance and competitiveness", Supply Chain Management: An International Journal, Vol. 22 No. 2, pp. 107-121.

Prajogo, D., and Olhager, J. (2012), "Supply chain integration and performance: The effects of long-term relationships, information technology and sharing, and logistics integration', International Journal of Production Economics, Vol. 135 No. 1, pp. 514522.

Prosman, E.-J., Scholten, K. and Power, D. (2016), “Dealing with defaulting suppliers using behavioural based governance methods: an agency theory perspective', Supply Chain Management: An International Journal, Vol. 21 No. 4, pp. 499-511.

PricewaterhouseCoopers (2015), “A Guide to Doing Business in Nigeria 2015”, PwC Nigeria, Doing Business in Nigeria. Available online at: https://www.pwc.com/ng/en/publications/doing-business.html. [Accessed on $16^{\text {th }}$ November 2019].

Ralston, M. P., Richey, R.G. and J. Grawe, S. (2017), "The past and future of supply chain collaboration: a literature synthesis and call for research", The International Journal of Logistics Management, Vol. 28 No. 2, pp. 508-530. 
Ramanathan, U., and Gunasekaran, A. (2014), "Supply chain collaboration: Impact of success in long-term partnerships", International Journal of Production Economics, Vol. 147, pp. 252-259.

Roy, V., Schoenherr, T., and Charan, P. (2020), “Toward an organizational understanding of the transformation needed for sustainable supply chain management: The concepts of force-field and differential efforts', Journal of Purchasing and Supply Management, Vol. 26 No. 3, pp.100-612.

Saunders, M., Lewis, P. and Thornhill, A. (2009), Research Methods for Business Students, $4^{\text {th }}$ ed., Pearson Education, Essex.

Schorsch, T., Wallenburg, C.M. and Wieland, A. (2017), "The human factor in SCM: Introducing a meta-theory of behavioral supply chain management', International Journal of Physical Distribution \& Logistics Management, Vol. 47 No.4, pp. 238-262.

Shukor, A.A.A., Newaz, M.S., Rahman, M.K. and Taha, A.Z. (2020), "Supply chain integration and its impact on supply chain agility and organizational flexibility in manufacturing firms", International Journal of Emerging Markets, Vol. ahead-of-print No. ahead-of-print. https://doi.org/10.1108/IJOEM-04-2020-0418.

Simangunsong, E., Hendry, L.C. and Stevenson, M. (2016), "Managing supply chain uncertainty with emerging ethical issues", International Journal of Operations \& Production Management, Vol. 36 No. 10, pp. 1272-1307.

Simatupang, T.M. and Sridharan, R. (2005), "The collaboration index: a measure for supply chain collaboration", International Journal of Physical Distribution \& Logistics Management, Vol. 35 No. 1, pp. 44-62.

Simatupang, T.M., and Sridharan, R. (2008), "Design for supply chain collaboration", Business Process Management Journal, Vol. 14 No.3, pp. 401-418.

Silverman, D. (2006), Interpreting Qualitative Data, $3^{\text {rd }}$ Edition., Sage, London.

Soosay, C.A., Hyland, P.W. and Ferrer, M. (2008), "Supply chain collaboration: capabilities for continuous innovation", Supply Chain Management: An International Journal, Vol. 13 No. 2, pp. 160-169.

Soosay, C.A. and Hyland, P. (2015), "A decade of supply chain collaboration and directions for future research", Supply Chain Management: An International Journal, Vol. 20 No. 6, pp. 613-630.

Storey, J., Emberson, C., Godsell, J. and Harrison, A. (2006), "Supply chain management: theory, practice and future challenge', International Journal of Operations \& Production Management, Vol. 26 No. 7, pp. 754-774.

Srinivasan, R. and Brush, T.H. (2006), "Supplier performance in vertical alliances: The effects of self-enforcing agreements and enforceable contracts". Organization science, Vol. 17 No. 4, pp. 436-452.

Svensson, G. and Bååth, H. (2008), "Supply chain management ethics: conceptual framework and illustration', Supply Chain Management: An International Journal, Vol. 13 No. 6, pp. 398-405.

Swanson, D. J., and Creed, A. S. (2014). "Sharpening the focus of force field analysis", "'Journal of Change Management', Vol. 14 No.1, pp. 28-47.

Tsanos, C.S. and Zografos, K.G. (2016), "The effects of behavioural supply chain relationship antecedents on integration and performance', Supply Chain Management: An International Journal, Vol. 21 No. 6, pp. 678-693.

Ugoani, J. (2019), "Role of Purchasing and Supply Management in Manufacturing Profitability in Nigeria". American Journal of Marketing Research, Vol. 5 No. 1, pp. $10-18$. 
Ugonna, C. U., Jolaoso, M. A., and Onwualu, A. P. (2015), "Tomato value chain in Nigeria: Issues, challenges and strategies", Journal of Scientific Research and Reports, pp. 501515.

Um, K. H., and Kim, S. M. (2019), “The effects of supply chain collaboration on performance and transaction cost advantage: The moderation and nonlinear effects of governance mechanisms", International Journal of Production Economics, Vol. 217, pp. 97-111.

United Nations (UN) (2019), "World Population Prospects 2019', Available at: "World Population Prospects 2019". [Assessed on 15 ${ }^{\text {th }}$ October 2019].

Vereecke, A. and Muylle, S. (2006), "Performance improvement through supply chain collaboration in Europe", International Journal of Operations \& Production Management, Vol. 26 No. 11, pp. 1176-1198.

Vlachos, I. and Dyra, S.C. (2020), "Theorizing coordination, collaboration and integration in multi-sourcing triads (B3B triads)", Supply Chain Management: An International Journal, Vol. 25 No. 3, pp. 285-300.

Voss, C., Tsikriktsis, N. and Frohlich, M. (2002), "Case research in operations management", International Journal of Operations and Production Management, Vol. 22 No. 2, pp. 195-219.

Walter, A., Müller, T.A., Helfert, G. and Ritter, T. (2003), "Functions of industrial supplier relationships and their impact on relationship quality", Industrial Marketing Management, Vol. 32 No. 2, pp. 159-169.

Whipple, J.M. and Russell, D. (2007), "Building supply chain collaboration: a typology of collaborative approaches", The International Journal of Logistics Management, Vol. 18 No. 2, pp. 174-196.

Wiengarten, F., Humphreys, P., Cao, G., Fynes, B. and McKittrick, A. (2010), “Collaborative supply chain practices and performance: exploring the key role of information quality", Supply Chain Management: An International Journal, Vol. 15 No. 6, pp. 463-473.

World Bank (2018), "Food, beverages and tobacco (\% of value added in manufacturing)", available at: https://data. worldbank.org/indicator/NV.MNF.FBTO.ZS.UN?end=2018\&start=2018 \&view=map\&year=2018 (Accessed 24 October 2018).

Wu, L. and Chiu, M.L. (2018), "Examining supply chain collaboration with determinants and performance impact: Social capital, justice, and technology use perspectives", International Journal of Information Management, Vol. 39, pp. 5-19.

Xing, Y., Liu, Y., Tarba, S., and Wood, G. (2020), "A cultural inquiry into ambidexterity in supervisor-subordinate relationship", The International Journal of Human Resource Management, Vol. 31 No. 2, pp. 203-231.

Yang, Z., Jiang, Y., and Xie, E. (2019), “'Buyer-supplier relational strength and buying firm's marketing capability: An outside-in perspective', Industrial Marketing Management, Vol. 82, pp. 27-37

Yin, R.K. (2009), Case Study Research: Design and Methods, 4th Ed., Sage, Thousand Oaks, CA.

Zhang, Q., and Cao, M. (2018), “Exploring antecedents of supply chain collaboration: Effects of culture and interorganizational system appropriation', International journal of Production Economics, Vol. 195, pp. 146-157. 


\section{Appendix A}

\begin{tabular}{|c|c|c|c|c|c|}
\hline Classification & Company & $\begin{array}{l}\text { Position of } \\
\text { interviewee }\end{array}$ & $\begin{array}{l}\text { Scope of } \\
\text { operations }\end{array}$ & $\begin{array}{l}\text { Interview } \\
\text { length } \\
\text { (minutes) }\end{array}$ & Relationship type \\
\hline \multirow[t]{2}{*}{ Food } & A & $\begin{array}{l}\text { Procurement } \\
\text { Manager }\end{array}$ & National level & 50 & \multirow[t]{2}{*}{ Long-term contract } \\
\hline & B & $\begin{array}{l}\text { Project } \\
\text { Manager }\end{array}$ & State level & 45 & \\
\hline \multirow[t]{2}{*}{ Dairy } & $\mathrm{C}$ & Sales Manager & $\begin{array}{l}\text { National } \\
\text { level }\end{array}$ & 60 & \multirow[t]{2}{*}{ Long-term contract } \\
\hline & $\mathrm{D}$ & $\begin{array}{l}\text { Logistics } \\
\text { Manager }\end{array}$ & Regional level & 60 & \\
\hline \multirow[t]{2}{*}{ Food } & $\mathrm{E}$ & $\begin{array}{l}\text { Commercial } \\
\text { Manager }\end{array}$ & National level & 45 & \multirow[t]{2}{*}{$\begin{array}{l}\text { Transactional } \\
\text { approach }\end{array}$} \\
\hline & $\mathrm{F}$ & $\begin{array}{l}\text { Supply and } \\
\text { Delivery } \\
\text { Manager }\end{array}$ & State level & 45 & \\
\hline \multirow[t]{2}{*}{ Food } & G & $\begin{array}{l}\text { Merchandise } \\
\text { Manager }\end{array}$ & National level & 45 & \multirow[t]{2}{*}{ Short-term contract } \\
\hline & $\mathrm{H}$ & $\begin{array}{l}\text { Product } \\
\text { Delivery } \\
\text { Manager }\end{array}$ & Regional level & 50 & \\
\hline \multirow[t]{2}{*}{ Beverage } & I & $\begin{array}{l}\text { Purchasing } \\
\text { Director }\end{array}$ & National level & 50 & \multirow[t]{2}{*}{ Long-term contract } \\
\hline & $\mathrm{J}$ & $\begin{array}{l}\text { Warehouse } \\
\text { Manager }\end{array}$ & State level & 45 & \\
\hline \multirow[t]{2}{*}{ Beverage } & K & $\begin{array}{l}\text { Supply } \\
\text { Executive }\end{array}$ & National level & 60 & \multirow[t]{2}{*}{ Long-term contract } \\
\hline & $\mathrm{L}$ & $\begin{array}{l}\text { Logistics } \\
\text { Manager }\end{array}$ & Regional level & 50 & \\
\hline \multirow[t]{2}{*}{ Beverage } & $\mathrm{M}$ & $\begin{array}{l}\text { General } \\
\text { Manager }\end{array}$ & National level & 65 & \multirow[t]{2}{*}{$\begin{array}{l}\text { Transactional } \\
\text { approach }\end{array}$} \\
\hline & $\mathrm{N}$ & $\begin{array}{l}\text { Inventory } \\
\text { Manager }\end{array}$ & State level & 45 & \\
\hline \multirow[t]{2}{*}{ Beverage } & $\mathrm{O}$ & $\begin{array}{l}\text { Distribution } \\
\text { Manager }\end{array}$ & National level & 50 & \multirow[t]{2}{*}{ Short-term contract } \\
\hline & $\mathrm{P}$ & Supply Director & Regional level & 50 & \\
\hline \multirow[t]{2}{*}{ Dairy } & Q & $\begin{array}{l}\text { Supply Chain } \\
\text { Manager }\end{array}$ & National level & 45 & \multirow[t]{2}{*}{$\begin{array}{l}\text { Transactional } \\
\text { approach }\end{array}$} \\
\hline & $\mathrm{R}$ & Plant Manager & Regional level & 40 & \\
\hline \multirow[t]{2}{*}{ Beverage } & $S$ & $\begin{array}{l}\text { Logistics } \\
\text { Manager }\end{array}$ & National level & 45 & \multirow[t]{2}{*}{ Long-term contract } \\
\hline & $\mathrm{T}$ & $\begin{array}{l}\text { Distribution } \\
\text { Manager }\end{array}$ & State level & 45 & \\
\hline \multirow[t]{2}{*}{ Food } & $\mathrm{U}$ & $\begin{array}{l}\text { Supply Chain } \\
\text { Manager }\end{array}$ & National level & 50 & \multirow[t]{2}{*}{ Long-term contract } \\
\hline & V & $\begin{array}{l}\text { Supply } \\
\text { Manager }\end{array}$ & Regional level & 45 & \\
\hline
\end{tabular}

Insert Table 1. Interview details 


\begin{tabular}{|c|c|c|c|}
\hline Research issue & Illustrative quotes & $\begin{array}{l}\text { Descriptive code } \\
\text { (second-order categories) }\end{array}$ & Third-order theme \\
\hline $\begin{array}{l}\text { Barriers associated with } \\
\text { managing supply } \\
\text { chains; issues that both } \\
\text { vendors and } \\
\text { manufactures } \\
\text { encounter. }\end{array}$ & 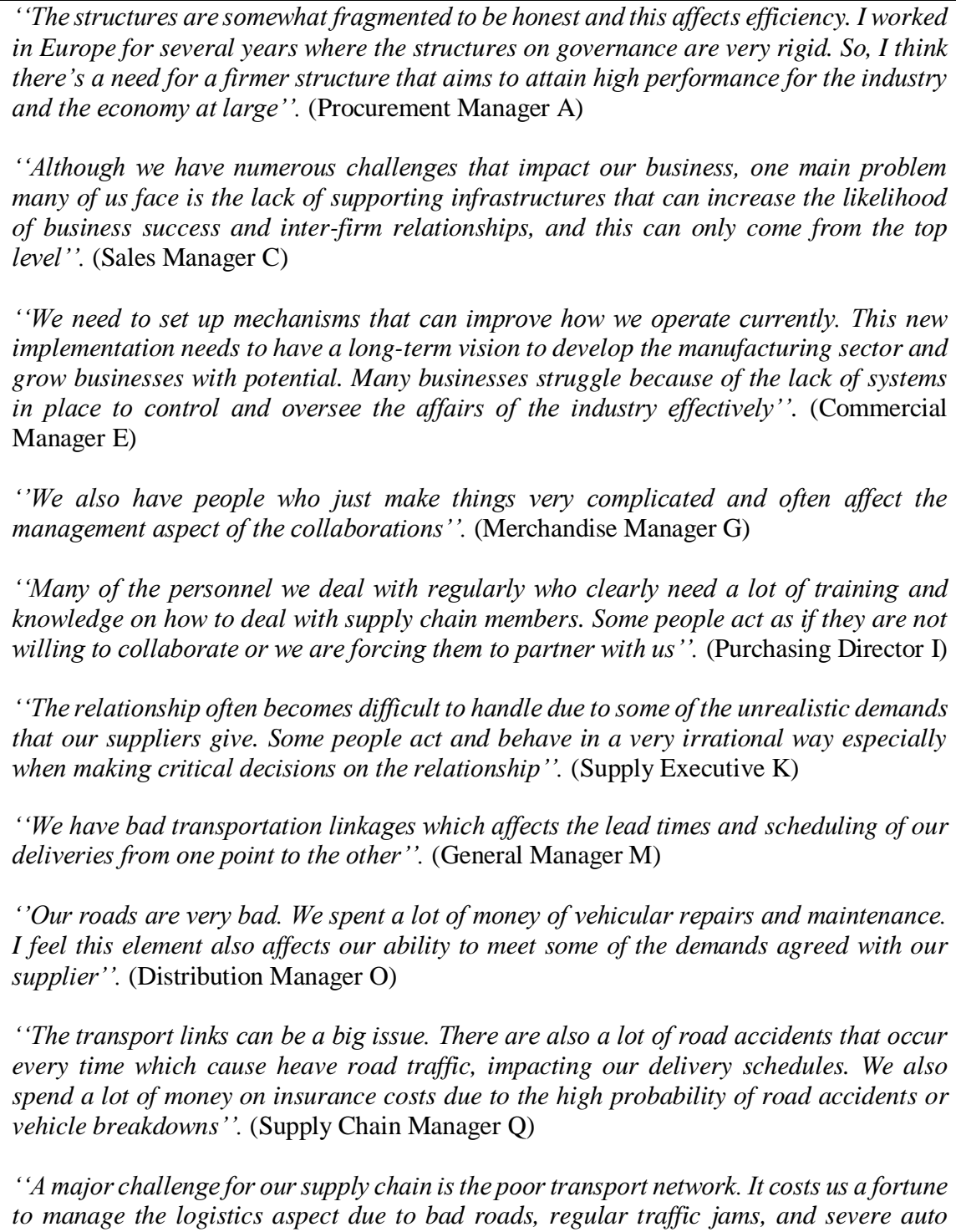 & $\begin{array}{l}\text { Implementation of mechanisms } \\
\text { and systems } \\
\text { People makes things } \\
\text { complicated } \\
\text { People: acting inappropriately, } \\
\text { and require training } \\
\text { People: actions, behaviours, and } \\
\text { irrationality } \\
\text { Bad transport linkage } \\
\text { Bad roads }\end{array}$ & $\begin{array}{l}\text { Human behaviour and } \\
\text { people }\end{array}$ \\
\hline
\end{tabular}




\begin{tabular}{|c|c|c|c|}
\hline & $\begin{array}{l}\text { crashes sometimes where people even die. But this is mainly because the roads need fixing } \\
\text { and the transport links need to be upgraded". (Logistics Manager S) }\end{array}$ & \begin{tabular}{|l} 
Poor transport network \\
\end{tabular} & \\
\hline Research issue & Illustrative quotes & $\begin{array}{l}\text { Descriptive code } \\
\text { (second-order categories) }\end{array}$ & Third-order theme \\
\hline \multirow[t]{2}{*}{$\begin{array}{l}\text { Barriers associated with } \\
\text { managing supply } \\
\text { chains; issues that both } \\
\text { vendors and } \\
\text { manufactures } \\
\text { encounter. }\end{array}$} & $\begin{array}{l}\text { "Corruption, bribery and other fraudulent practices are also factors that affect our ability } \\
\text { to perform well. Some companies bribe to get specific favours and superiority from } \\
\text { manufacturing firms which produces unfair competition". (Supply Chain Manager U) } \\
\text { "Many firms in the supply chain are also owned by executives and top managers in } \\
\text { manufacturing firms. So, there is a lot of insider abuse and negative use of power for } \\
\text { personal favouritism and partiality". (Supply Manager V) } \\
\text { "Due to the nature of the business environment and the weak corporate governance in the } \\
\text { supply chain, we have many businesses existing but are owned by some senior people in } \\
\text { the manufacturing firms and what they do is to use their position to seek their personal } \\
\text { benefits first before anything else. This of course creates a market that benefits some and } \\
\text { not all". (Logistics Manager D) } \\
\text { "We also have security and safety concerns from warehousing stage up until the delivery } \\
\text { stage for retailers and end consumers. We have had issues of burglary and theft on our } \\
\text { storage facilities in the past which caused massive delays on product deliveries for our } \\
\text { buyers and late payment for our suppliers and affected our collaboration adversely". } \\
\text { (Supply and Delivery Manager F) } \\
\text { "Goods and inventory go missing all the time. Our storage facility was raided and set on } \\
\text { fire some time ago. We have learnt from that horrible experience and we now pay a lot for } \\
\text { security and safety because of the negative impact that it can cause for the supply chain". } \\
\text { (Product Delivery Manager H) } \\
\text { "A few years back, we had an incident that caused enormous delays for our products } \\
\text { because one of our main hubs in the country was vandalized by some local unemployed } \\
\text { people. A lot of materials were stolen and that took a while to recover". (Warehouse } \\
\text { Manager J) }\end{array}$ & $\begin{array}{l}\text { Corruption, bribery, fraud } \\
\text { Insider abuse, negative use of } \\
\text { power } \\
\text { Self-interest seeking and } \\
\text { unethical practices }\end{array}$ & Safety and security concerns \\
\hline & Illustrative quotes & $\begin{array}{l}\text { Descriptive code } \\
\text { (second-order categories) }\end{array}$ & Third-order theme \\
\hline $\begin{array}{l}\text { Barriers associated with } \\
\text { managing supply } \\
\text { chains; issues that both }\end{array}$ & "I feel our technological landscape needs rapid advancement". (Logistics Manager l) & Weak technology & $\begin{array}{l}\text { Weak information } \\
\text { technology infrastructure }\end{array}$ \\
\hline
\end{tabular}




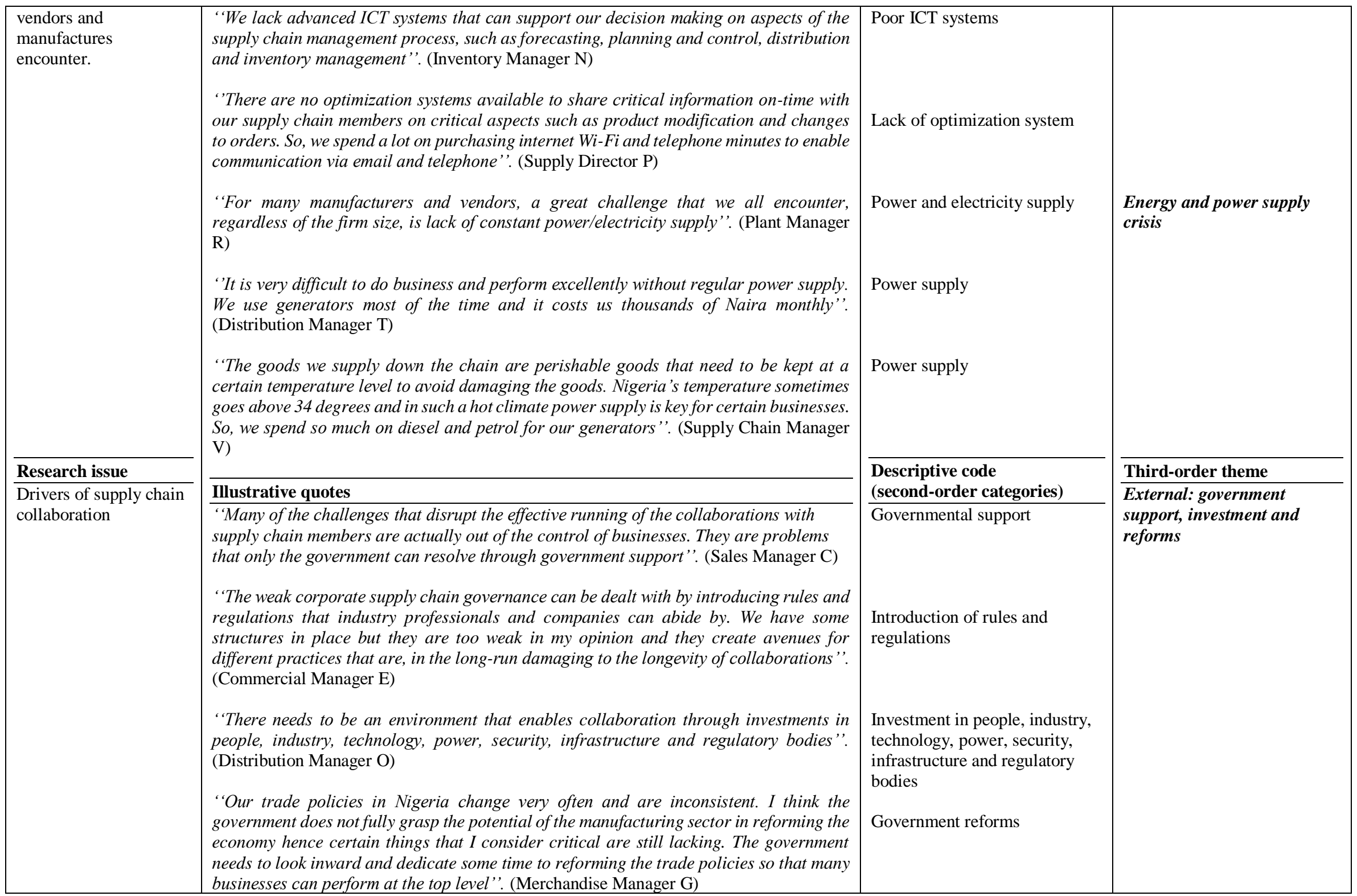




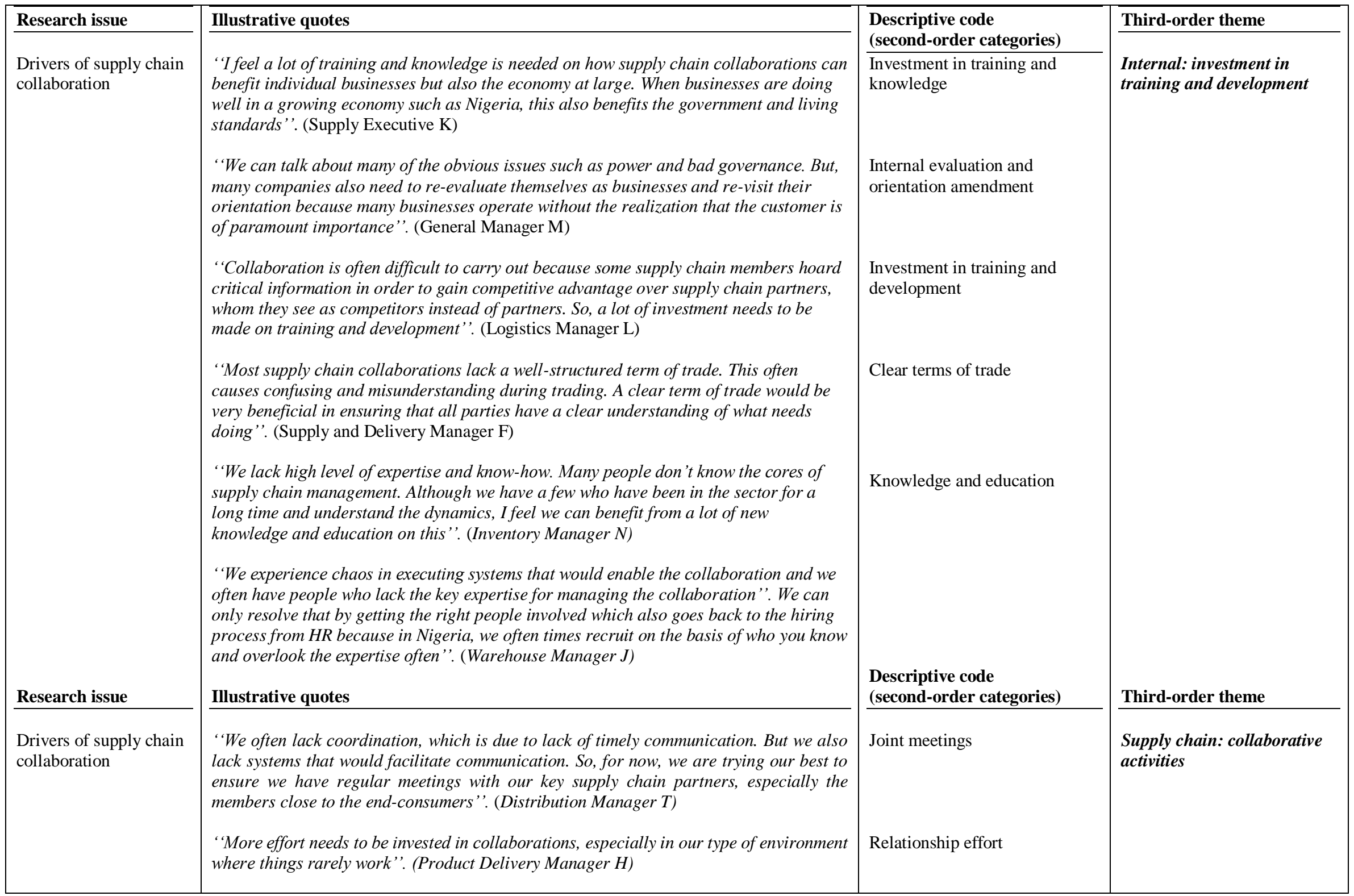




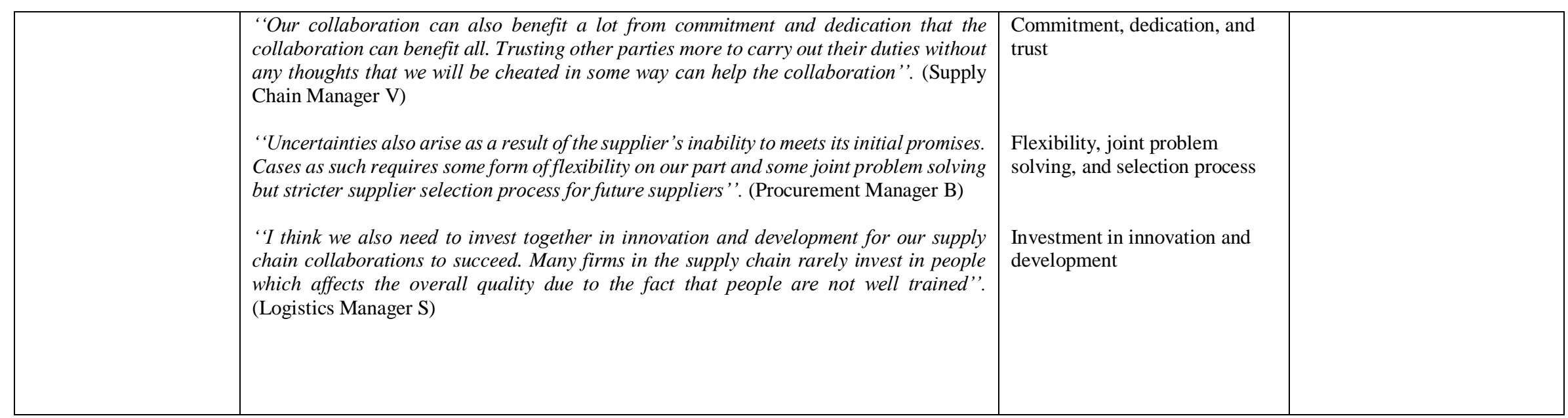

Insert Table 2. Interview findings 


\begin{tabular}{|c|c|c|}
\hline \multicolumn{3}{|l|}{$\begin{array}{l}\text { Restraining Forces of SC } \\
\text { collaboration in an emerging } \\
\text { market }\end{array}$} \\
\hline Internal firm level & Supply chain level & External environment level \\
\hline $\begin{array}{l}\text { At the internal firm level, } \\
\text { restraining forces of SC } \\
\text { collaboration were identified as } \\
\text { factors related to human } \\
\text { behaviour, people, and internal } \\
\text { ethical issues. }\end{array}$ & $\begin{array}{l}\text { At the supply chain level, } \\
\text { restraining forces of SC } \\
\text { collaboration were identified as } \\
\text { factors related to weak } \\
\text { information technology } \\
\text { infrastructure, poor structure, } \\
\text { governance, and support } \\
\text { systems. }\end{array}$ & $\begin{array}{l}\text { At the external environment } \\
\text { level, restraining forces of SC } \\
\text { collaboration were identified as } \\
\text { are factors related to safety and } \\
\text { security concerns, poor } \\
\text { transportation infrastructure, } \\
\text { energy and power supply } \\
\text { crisis. }\end{array}$ \\
\hline \multicolumn{3}{|l|}{$\begin{array}{l}\text { Driving Forces of SC } \\
\text { collaboration in an emerging } \\
\text { market }\end{array}$} \\
\hline Internal firm level & Supply chain level & External environment level \\
\hline $\begin{array}{l}\text { At the internal firm level, } \\
\text { driving forces of SC } \\
\text { collaboration were identified as } \\
\text { factors related to investment in } \\
\text { training and development, and } \\
\text { evaluation of processes. }\end{array}$ & $\begin{array}{l}\text { At the supply chain level, } \\
\text { driving forces of SC } \\
\text { collaboration were identified as } \\
\text { factors related to investment in } \\
\text { collaborative activities such as } \\
\text { information sharing, joint } \\
\text { relationship effort, and } \\
\text { dedicated investment. }\end{array}$ & $\begin{array}{l}\text { The external environment } \\
\text { level, driving forces of SC } \\
\text { collaboration were identified as } \\
\text { factors related to governmental } \\
\text { support, investments and } \\
\text { reforms. }\end{array}$ \\
\hline
\end{tabular}

Insert Table 3 about here: Categories of restraining and driving forces of SC collaboration in an emerging market 


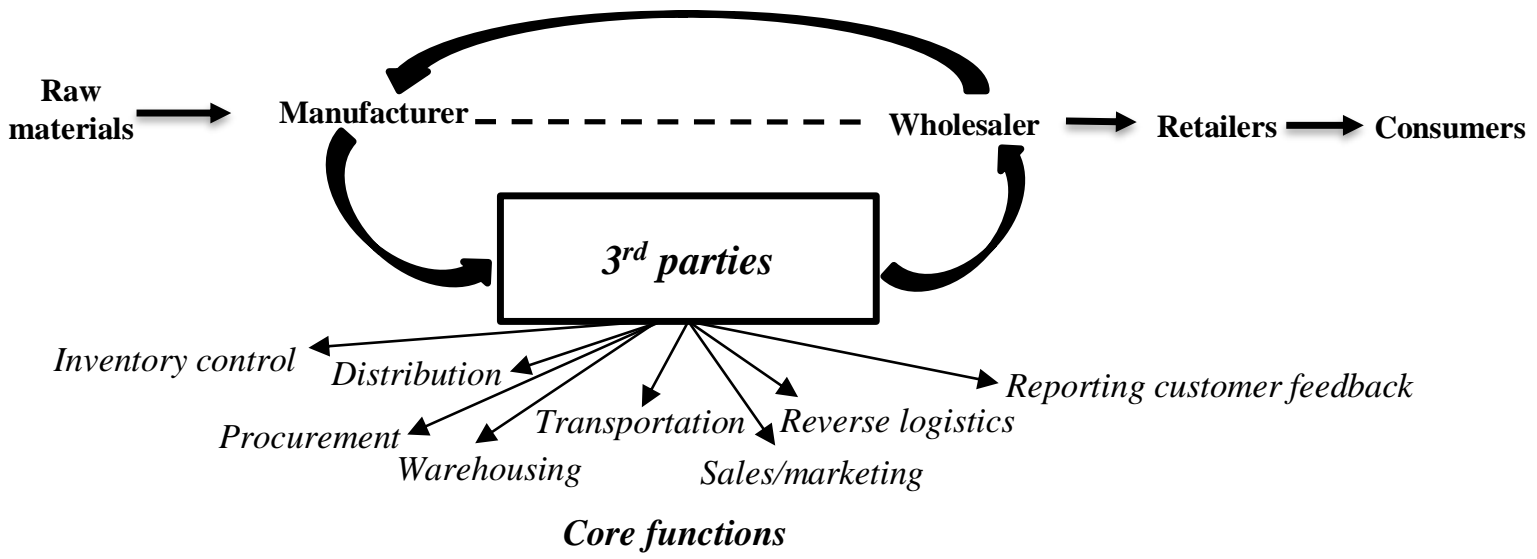

Figure 1. Supply chain in an emerging market's food and beverage sector

\begin{tabular}{|c|c|c|}
\hline $\begin{array}{l}\text { Restraining forces } \\
\text { associated with supply } \\
\text { chain collaboration } \\
\text { Internal firm level } \\
\text {-Human behaviour \& people } \\
\text {-Internal ethical issues } \\
\text { Supply chain level } \\
\text {-Weak information technology } \\
\text { infrastructure } \\
\text {-Poor structure, governance, \& } \\
\text { support systems } \\
\text { External environment level } \\
\text {-Safety \& security concerns } \\
\text {-Poor transportation } \\
\text { infrastructure } \\
\text {-Energy and power supply crisis }\end{array}$ & $\begin{array}{c}\text { Supply chain } \\
\text { collaboration } \\
\text { in an emerging } \\
\text { market }\end{array}$ & $\begin{array}{l}\text { Driving forces of supply } \\
\text { chain collaboration } \\
\text { Internal firm level } \\
\text {-Investment in training and } \\
\text { development } \\
\text {-Process evaluation } \\
\text { Supply chain level } \\
\text {-Collaborative activities } \\
\text { External environment level } \\
\text {-Government support, } \\
\text { investment and reforms }\end{array}$ \\
\hline
\end{tabular}

Figure 2: Restraining forces and driving forces of supply chain collaboration in an emerging market 


\section{Appendix B - Interview protocol}

1) Please, can you describe the nature of your relationship with your supplier or buyer?

- What is the length of your dealings with them as supply chain partners?

- What is the nature of the products that you buy from or supply to them?

- Explain the nature of the business environment where you carry out your supply chain activities?

- Is your supplier or buyer located in the same city/region as you? If not, where are they situated?

2) Please, can you explain the idea of supply chain collaboration in the context of your relationship?

- What does supply chain collaboration entail between you and your supplier or buyer?

- How important is the idea of collaboration for your business relationship?

- How difficult is it to establish, develop, and maintain collaborative relationships in your business environment?

- What are some of the benefits of a collaborative relationship for you and your supplier or buyer?

3) Please, can you describe the restraining forces of your supply chain collaboration?

- What are the factors that hinder your collaboration between you and your supplier or buyer?

- What ways do these identified restraining forces impact collaboration between you and your supplier or buyer?

- Can you explain the underlying causes of these restraining forces?

- How willing are you and your supplier or buyer toward adopting approaches that will develop collaboration?

4) Please, can you describe the driving forces of your supply chain collaboration?

- What are the factors that promote collaboration between you and your supplier or buyer?

- What ways do these identified drivers impact collaboration between you and your supplier or buyer?

- How do you implement these drivers and communicate them to your supplier or buyer?

- What things have changed since these drivers have been identified?

- How well has your relationship been since you both realised these drivers? 